\title{
Biopolymer-Based Nanohydroxyapatite Composites for the Removal of Fluoride, Lead, Cadmium, and Arsenic from Water
}

\author{
M. Shanika Fernando, A. K. D. V. K. Wimalasiri, Karolina Dziemidowicz, Gareth R. Williams, \\ K. R. Koswattage, D. P. Dissanayake, K. M. Nalin de Silva, and Rohini M. de Silva*
}

Cite This: ACS Omega 2021, 6, 8517-8530

Read Online

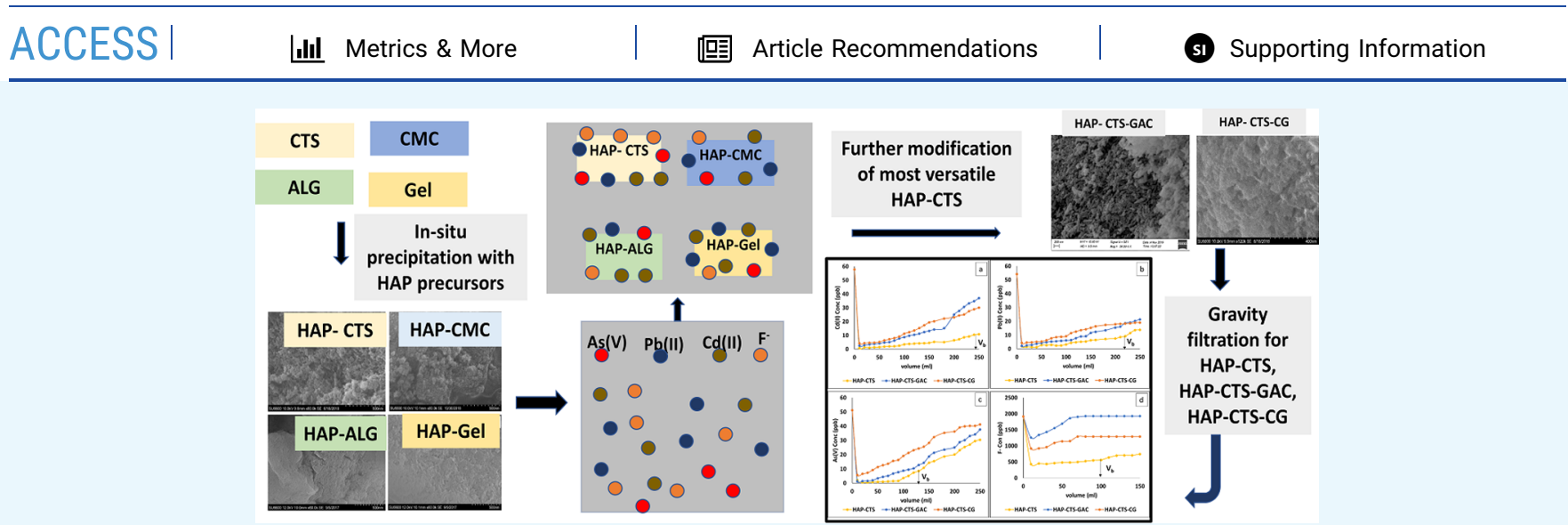

ABSTRACT: In this study, hydroxyapatite (HAP) nanocomposites were prepared with chitosan (HAP-CTS), carboxymethyl cellulose (HAP-CMC), alginate (HAP-ALG), and gelatin (HAP-GEL) using a simple wet chemical in situ precipitation method. The synthesized materials were characterized using scanning electron microscopy, Fourier transform infrared spectroscopy, X-ray diffraction, Brunauer-Emmett-Teller surface area analysis, and thermogravimetric analysis. This revealed the successful synthesis of composites with varied morphologies. The adsorption abilities of the materials toward $\mathrm{Pb}(\mathrm{II}), \mathrm{Cd}(\mathrm{II}), \mathrm{F}^{-}$, and $\mathrm{As}(\mathrm{V})$ were explored, and HAP-CTS was found to have versatile adsorption properties for all of the ions, across a wide range of concentrations and $\mathrm{pH}$ values, and in the presence of common ions found in groundwater. Additionally, X-ray photoelectron spectroscopy and energydispersive X-ray spectroscopy confirmed the affinity of HAP-CTS toward multi-ion mixture containing all four ions. HAP-CTS was hence engineered into a more user-friendly form, which can be used to form filters through its combination with cotton and granular activated carbon. A gravity filtration study indicates that the powder form of HAP-CTS is the best sorbent, with the highest breakthrough capacity of 3000, 3000, 2600, and $2000 \mathrm{~mL} / \mathrm{g}$ for $\mathrm{Pb}(\mathrm{II}), \mathrm{Cd}(\mathrm{II}), \mathrm{As}(\mathrm{V})$, and $\mathrm{F}^{-}$, respectively. Hence, we propose that HAP-CTS could be a versatile sorbent material for use in water purification.

\section{INTRODUCTION}

Water contamination is often caused by inorganic species such as heavy metal ions and fluoride $\left(\mathrm{F}^{-}\right)$. Due to their high stability in the environment, such contaminants are considered to be particularly hazardous and have been identified at unsafe levels in many parts of the world. ${ }^{1,2}$ The ingestion of these ions can cause both acute and chronic diseases, ${ }^{3-5}$ such as chronic kidney disease with unknown etiology $(\mathrm{CKDu})$. The latter is particularly prevalent in Sri Lanka, and, while its cause remains unknown, the incidence is correlated with the intake of water contaminated with $\mathrm{F}^{-}$or metal ions such as $\mathrm{Pb}(\mathrm{II}), \mathrm{Cd}(\mathrm{II})$, and $A s(V))^{3,6-9}$ The development of cost-effective methods to remove these contaminants from water is hence vital.

Effective sorbents should possess high affinity for target pollutants, ideally being able to adsorb several contaminants simultaneously and to remove them rapidly. A large number of materials have been developed to remove both organic and inorganic contaminants from water. ${ }^{10-12}$ However, some can act as sources of secondary pollution. ${ }^{11,12}$ This can be prevented by using nontoxic and biodegradable adsorbents. ${ }^{13}$ Nano-hydroxyapatite (HAP) and its composites have been shown to be effective adsorbents for water pollutants. HAP has low toxicity, biocompatibility, ${ }^{14}$ and versatile sorption properties toward both anions and cations. However, using nanoparticles alone as a sorbent brings challenges, and they need to be mounted into a carrier medium to generate practical filter materials. Hence, this work is focused on

Received: January 18, 2021

Accepted: March 8, 2021

Published: March 18, 2021

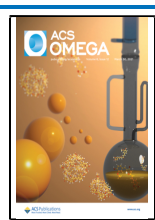



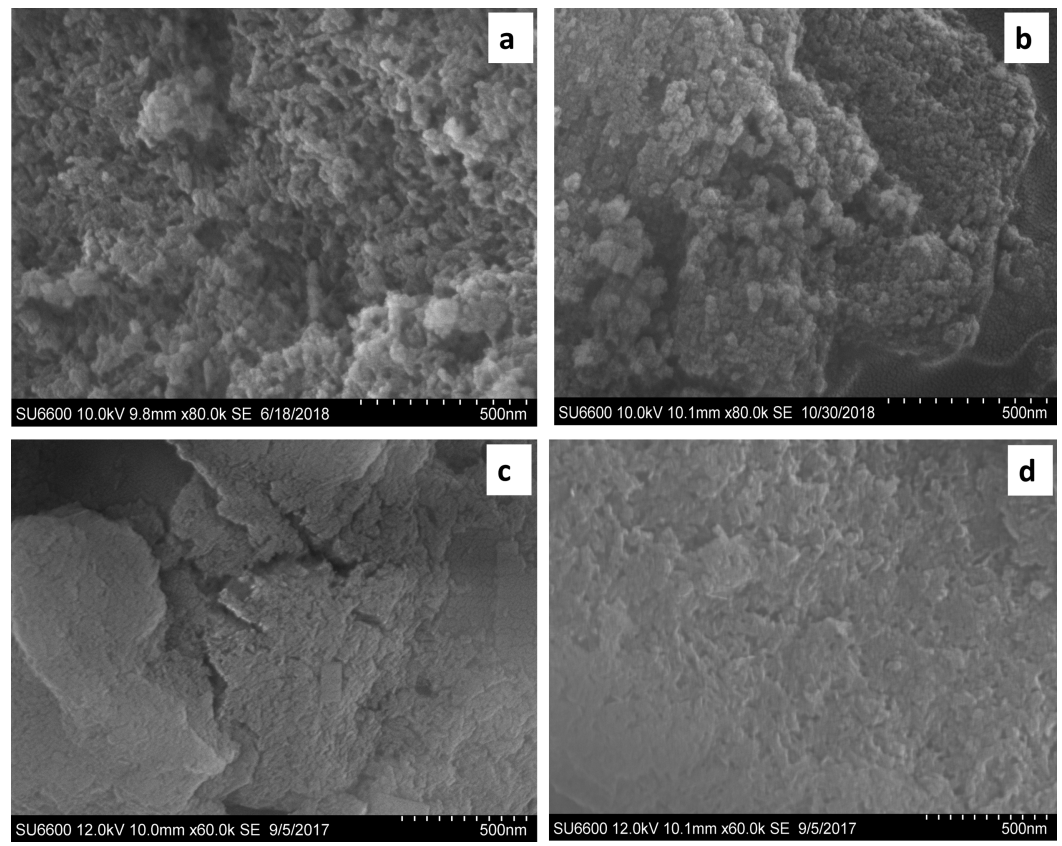

Figure 1. SEM images of the optimized HAP-biopolymer systems: (a) HAP-CTS, (b) HAP-CMC, (c) HAP-ALG, and (d) HAP-GEL.
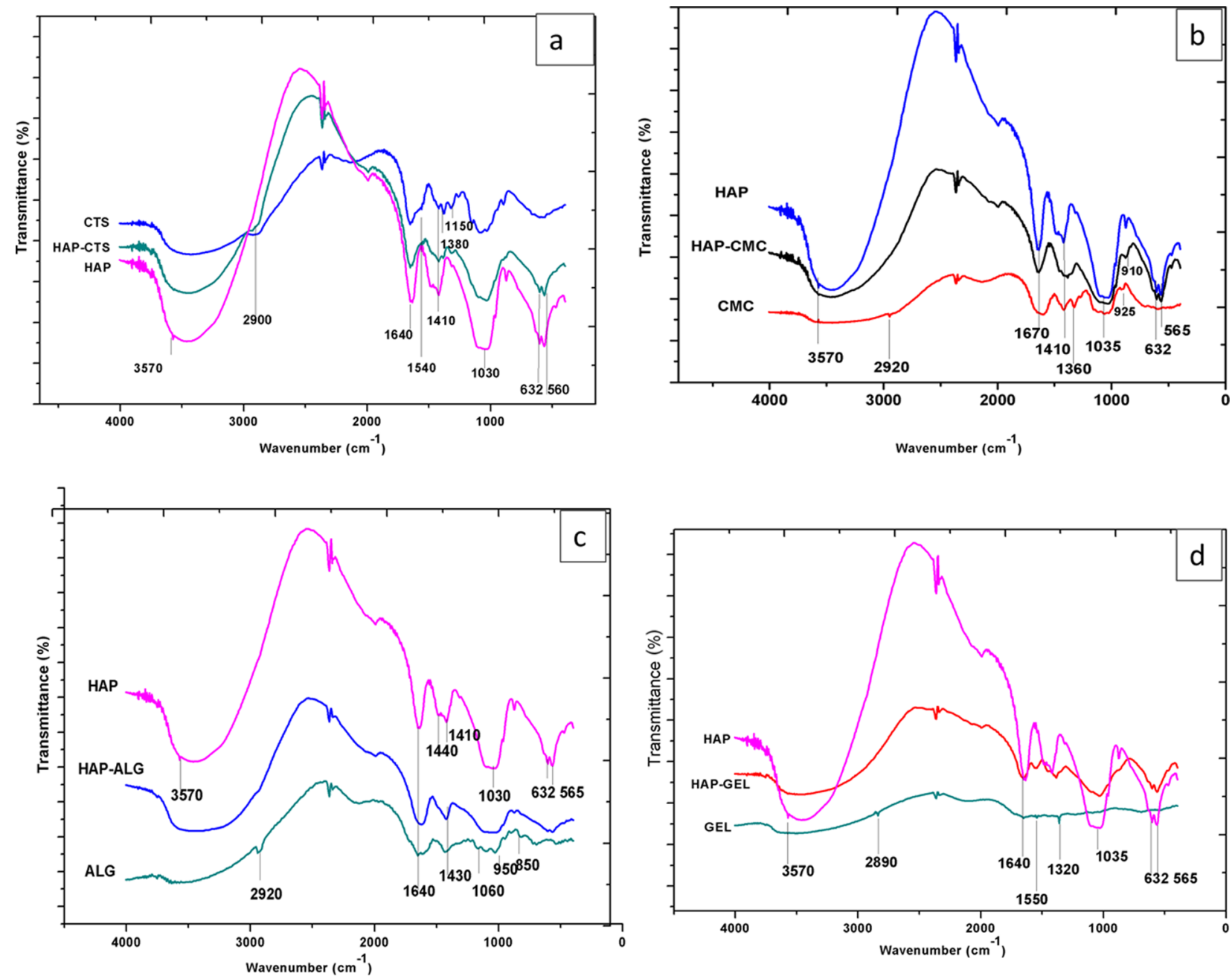

Figure 2. FTIR spectra of (a) HAP-CTS, (b) HAP-CMC, (c) HAP-ALG, and (d) HAP-GEL. 
combining HAP with biopolymers to develop more versatile and stronger filter materials. ${ }^{15-19}$

In addition to being nontoxic, natural biopolymers such as chitosan, ${ }^{20-23}$ cellulose, ${ }^{24}$ carboxymethyl cellulose, ${ }^{25,26}$ sodium alginate, $^{27}$ lignin, ${ }^{28}$ pectin, ${ }^{29}$ and gelatin ${ }^{30,31}$ have chelating properties. Several studies have explored the sorption properties of HAP biopolymer composites for contaminants including $\mathrm{Pb}(\mathrm{II}), \mathrm{Cd}(\mathrm{II}), \mathrm{As}(\mathrm{V})$, and $\mathrm{F}^{-} .^{15-17,29,32-43}$ The properties of these composites vary depending on the synthesis method and the conditions applied in the adsorption studies. Only a few studies have explored competitive adsorption properties in multi-ion systems. In addition, there is minimal knowledge on how the type of polymer incorporated and the component ratios affect the sorption properties of HAP biopolymer composites. In this study, we sought to redress this lack of understanding. Four biopolymers, chitosan (CTS), carboxymethyl cellulose (CMC), sodium alginate (ALG), and gelatin (GEL), were explored. HAP nanocomposites with these biopolymers were prepared, and their sorption properties toward $\mathrm{Pb}(\mathrm{II}), \mathrm{Cd}(\mathrm{II}), \mathrm{As}(\mathrm{V})$, and $\mathrm{F}^{-}$were investigated.

\section{RESULTS}

Initially, nanocomposites with different HAP to polymer ratios were synthesized, and the optimal ratio for each composite was selected based on an initial comparative adsorption study. This is discussed in detail in Section S.1, Supporting Information (Figures S1-S4). HAP-CTS 60\%, HAP-CMC 50\%, HAP-ALG $50 \%$, and HAP-GEL 50\% were identified as the systems with the most potent adsorption properties toward $\mathrm{Pb}(\mathrm{II}), \mathrm{Cd}(\mathrm{II})$, $\mathrm{F}^{-}$, and $\mathrm{As}(\mathrm{V})$. Hereafter, these optimized composites will be referred to as HAP-CTS, HAP-CMC, HAP-ALG, and HAPGEL.

2.1. Characterization of Materials. Scanning electron micrographs (SEM) were used to investigate the morphology of the nanocomposites, as shown in Figure 1. HAP-CTS (Figure 1a) can be seen to have a highly porous structure with interconnected rod-shaped particles on the 20-50 nm scale. The SEM of HAP-CMC (Figure 1b) also shows a porous structure and a grainlike morphology with highly agglomerated spherical-shaped nanoparticles. However, the morphology and porosity of HAP-ALG are very different (Figure 1c). The structure is less porous, with embedded nanoparticles in the polymer matrix. HAP-GEL (Figure 1d) also has fewer pores and apparently larger particle sizes.

Brunauer-Emmett-Teller (BET) analysis was performed to measure the specific surface area (SSA), pore size, and pore volume (see Figure S5). SSA values for HAP-CTS, HAPCMC, HAP-ALG, and HAP-GEL were 191.0, 90.6, 83.8, and $80.0 \mathrm{~m}^{2} / \mathrm{g}$, respectively. The pore volumes were, respectively, calculated as $4.02 \times 10^{-1}, 1.9 \times 10^{-1}, 1.2 \times 10^{-1}$, and $3.3 \times$ $10^{-1} \mathrm{~cm}^{3} / \mathrm{g}$. When the four systems are compared, HAP-CTS shows the highest SSA and pore volume, which is consistent with the SEM data in Figure 1.

Fourier transform infrared (FTIR) spectra of HAP-CTS, HAP-CMC, HAP-ALG, and HAP-GEL are presented in Figure 2. All of the composites exhibit characteristic bands corresponding to HAP. For example, $\mathrm{OH}$ can be identified as a broad band around $3500 \mathrm{~cm}^{-1}$. Vibrations present at 1030 , 905 , and $565 \mathrm{~cm}^{-1}$ in all composites are attributed to the stretching vibration modes of $\mathrm{PO}_{4}{ }^{3-} \cdot{ }^{10,44}$ All four HAPbiopolymer composites display a broadening of the adsorption band around $3300-3500 \mathrm{~cm}^{-1}$ toward the low-frequency side and the absence of the characteristic HAP OH stretch at 3570 $\mathrm{cm}^{-1} \cdot{ }^{45,46}$ In Figure 2a, characteristic bands for chitosan are found at around $2900 \mathrm{~cm}^{-1}$ in HAP-CTS and arise due to $\mathrm{CH}_{2}$ stretching vibrations. The bands present at 1540 and 1410 $\mathrm{cm}^{-1}$ can be attributed to the symmetric and asymmetric stretching of $\mathrm{COO}$ groups. In addition, a broad band from 3400 to $3100 \mathrm{~cm}^{-1}$ arises from stretching vibrations of $\mathrm{N}-\mathrm{H}$ functional groups of chitosan. ${ }^{33,39,47}$ Bands can also be identified at 1150 and $1380 \mathrm{~cm}^{-1}$, corresponding to $\mathrm{C}-\mathrm{O}$ stretching and $\mathrm{CH}$ bending of chitosan. ${ }^{48}$

The FTIR spectrum of HAP-CMC (Figure 2b) shows a broad band around $1440-1360 \mathrm{~cm}^{-1}$ due to asymmetric carboxylate stretching and $\mathrm{OH}$ bending modes of CMC. These usually occurred at 1410 and $1360 \mathrm{~cm}^{-1}, 49,50$ but in the composite overlap with the carbonate peak of HAP at 1440 $\mathrm{cm}^{-1}$. C-O vibrations of CMC can also be observed in HAP$\mathrm{CMC}$ at $925 \mathrm{~cm}^{-1}$, with a blue shift. ${ }^{51,52}$

The FTIR spectrum of HAP-ALG is given in Figure 2c. In ALG, there are bands at 950 and $1060 \mathrm{~cm}^{-1}$ due to stretching vibrations of the carboxylic groups, while the band at $850 \mathrm{~cm}^{-1}$ is from $\mathrm{OH}$ bending. In the HAP-ALG composite, these bands appear as one broad band due to overlapping with HAP bands at the same positions. The band at $1430 \mathrm{~cm}^{-1}$ for alginate arises due to $\mathrm{CH}_{2}$ bending, ${ }^{53,54}$ and can also be seen with HAP-ALG. In addition, the presence of all of the characteristic HAP bands again confirms the formation of a binary complex. $^{55}$

The FTIR spectrum of neat gelatin (Figure 2d) shows distinct bands at 1320 and $1550 \mathrm{~cm}^{-1}$ from amide groups. ${ }^{56,57}$ These vibrations can also be identified in HAP-GEL, confirming the successful incorporation of gelatin. Again, the HAP bands are also visible, confirming the successful synthesis of the composite material. ${ }^{58,59}$

$\mathrm{X}$-ray diffraction (XRD) patterns of the four HAPbiopolymer systems, neat $\mathrm{HAP}$, and the raw biopolymers are overlaid in Figure 3. This reveals that neat HAP has characteristic Bragg reflections at 26, 29, 32-34, 40, 46-54, and $63^{\circ}$, which matches with the literature. ${ }^{44,60}$ HAP-GEL contains more crystalline $\mathrm{HAP}^{61,62}$ than the other systems, which is consistent with the SEM images (Figure 1). Incorporation of the other polysaccharides led to broad

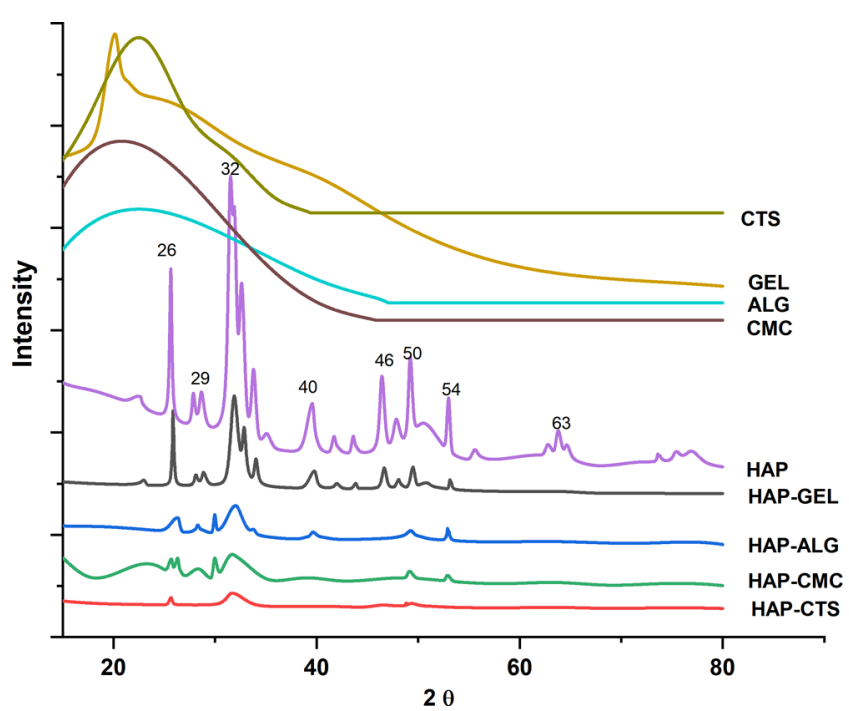

Figure 3. XRD patterns of the optimized HAP-biopolymer systems and raw materials. 


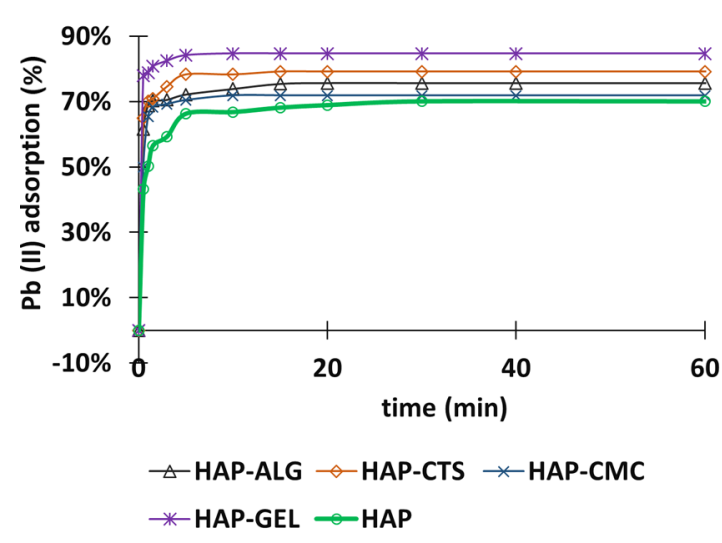

(a)

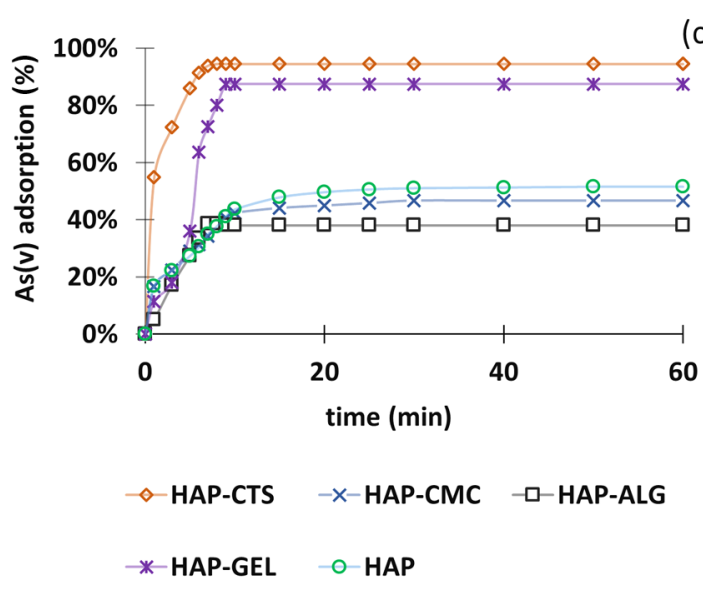

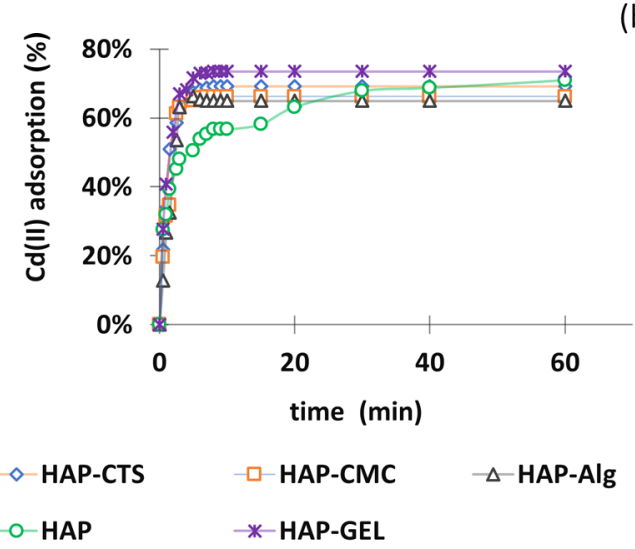

(b)

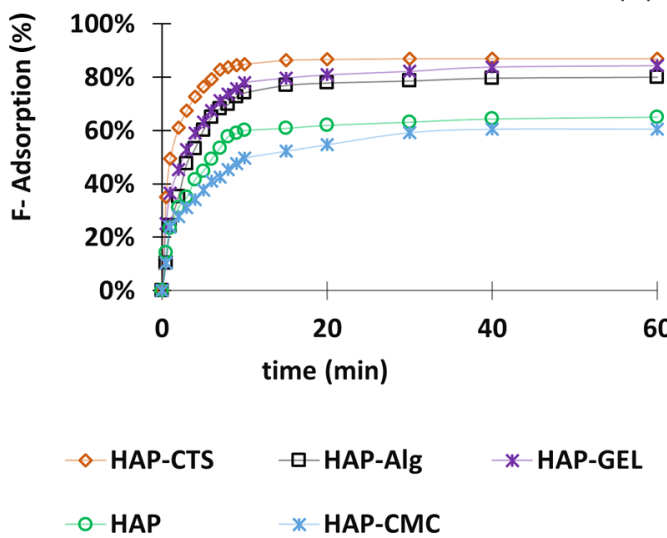

Figure 4. Adsorption vs time plots for (a) $\mathrm{Pb}(\mathrm{II}),(\mathrm{b}) \mathrm{Cd}(\mathrm{II}),(\mathrm{c}) \mathrm{As}(\mathrm{V})$, and (d) $\mathrm{F}^{-}$on HAP-biopolymer nanocomposites, at a solution pH of 6.3, $6,2,6.9$, and 6.7 , respectively.

peaks and reduced HAP crystallinity. ${ }^{42,63}$ However, all four HAP-biopolymer nanocomposites show a peak corresponding to neat HAP between 32 and $34^{\circ}$, which is consistent with the successful incorporation of HAP with the biopolymers.

Thermogravimetric studies (TGA) were conducted with all four biopolymer nanocomposites (Figure S6). All were found to contain a small amount of water $(5-10 \%)$ and were stable up to $200{ }^{\circ} \mathrm{C}$. This augers well for their use in water purification applications.

2.2. Adsorption Studies. 2.2.1. Effect of Time. The adsorption capacity as a function of time was studied separately for $\mathrm{Pb}(\mathrm{II}), \mathrm{Cd}(\mathrm{II}), \mathrm{As}(\mathrm{V})$, and $\mathrm{F}^{-}$, using an initial concentration of $1500,400,1$, and $40 \mathrm{ppm}$. This resulted in a solution $\mathrm{pH}$ of $6.3,6,2,6.9$, and 6.7 , respectively. The uptake data are presented in Figure 4. All of the nanocomposites showed initial fast adsorption due to the availability of a large number of active binding sites and reached a steady state in less than $30 \mathrm{~min}$. For $\mathrm{Pb}(\mathrm{II})$ (Figure 4a), HAP-GEL shows a maximum of $85 \%$ absorption, which is reached within $5 \mathrm{~min}$. HAP-CTS, HAP-CMC, and HAP-ALG reach maximum absorptions of 79,76 , and $74 \%$, respectively, attained within 5, 20, and $10 \mathrm{~min}$. A similar trend was observed for Cd(II) (Figure 4b), with 74\% absorption on HAP-GEL within $10 \mathrm{~min}$ while HAP-CTS, HAP-CMC, and HAP-ALG reached 69, 66, and $65 \%$ in this time.

Plots of $\mathrm{F}^{-}$and $\mathrm{As}(\mathrm{V})$ adsorption vs time are shown in Figure 4c,d. HAP-CTS is the most effective adsorbent, reaching the maximum adsorption with the shortest contact time. For $\mathrm{F}^{-}$, HAP-CTS shows $85 \%$ absorption within $10 \mathrm{~min}$, while HAP-GEL and HAP-ALG give 78 and 74\%, respectively, within 15 and $20 \mathrm{~min}$. Considering $\mathrm{As}(\mathrm{V})$ adsorption, again, HAP-CTS shows the best properties, yielding 91\% adsorption within $6 \mathrm{~min}$, while HAP-GEL and HAP-ALG gave 87 and $45 \%$ adsorption within 10 and $20 \mathrm{~min}$, respectively. HAPCMC shows poor absorption properties for both $\mathrm{F}^{-}$and As $(V)$, performing less well than neat HAP for As $(V)$. The four HAP biopolymer composites clearly have both cationic and anionic adsorption sites, owing to the amalgamation of the biopolymer with HAP. HAP-GEL was the best adsorbent for $\mathrm{Pb}(\mathrm{II})$ and $\mathrm{Cd}(\mathrm{II})$, while HAP-CTS showed the best sorption properties toward all ions examined and identified as the most versatile adsorbent. This can be attributed to the presence of $\mathrm{NH}_{2}$ in CTS as well as its cationic nature compared to the other three polymers; in addition, this can be attributed to the higher surface area of HAP-CTS that resulted in $190 \mathrm{~m}^{2} / \mathrm{g}$.

2.2.2. Effect of $\mathrm{pH}$. The $\mathrm{pH}$ of a solution is one of the main factors that influence the process of adsorption since it affects the degree of ionization and the surface charge of the particles. Neat HAP is not stable at $\mathrm{pH}$ values below 3 and tends to dissolve. However, all four HAP biopolymer nanocomposites

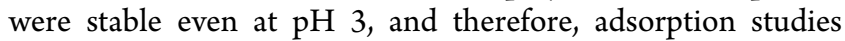
were conducted between $\mathrm{pH} 3$ and 11 for $\mathrm{Pb}(\mathrm{II}), \mathrm{Cd}(\mathrm{II})$, fluoride, and $\mathrm{As}(\mathrm{V})$. The incubation time was $1 \mathrm{~h}$. The effect of $\mathrm{pH}$ on adsorption of $\mathrm{Pb}$ (II) and $\mathrm{Cd}(\mathrm{II})$ is depicted in Figures S7 and S8. The adsorption percentage gradually increases from $\mathrm{pH} 3$ to 8 , before reaching a plateau at $\mathrm{pH} 10$ due to precipitation of $\mathrm{Pb}(\mathrm{II})$ and $\mathrm{Cd}(\mathrm{II})$ hydroxides. Figure $\mathrm{S} 9$ exhibits the effect of $\mathrm{pH}$ on the adsorption of $\mathrm{F}^{-}$. All four 
composites show a decrease in adsorption percentage as the $\mathrm{pH}$ increases from $\mathrm{pH} 3$ to 7 . Above $\mathrm{pH} 8$, there is a drastic drop in adsorption of $\mathrm{F}^{-}$. This is due to greater competition with $\mathrm{OH}^{-}$ions in solution at higher $\mathrm{pH}$ values. As(V) adsorption as a function of $\mathrm{pH}$ is depicted in Figure S10. The extent of absorption was greatest at $\mathrm{pH} 3-6$, after which a decline can be observed. Out of the four nanocomposites, HAP-CTS was identified as the most versatile because it shows the best adsorption properties toward all four contaminants over a wide range of $\mathrm{pH}$ values, including at neutral $\mathrm{pH}$.

2.2.3. Adsorption Isotherms. Adsorption isotherm models can be used to characterize the uptake behavior of materials. The results of concentration-dependent batch adsorption studies were fitted with the commonly used Langmuir and Freundlich isotherm models. The linearized form of the Langmuir adsorption isotherm, which is used to describe monolayer adsorption, is given by

$$
C_{\mathrm{e}} / \mathrm{Q}_{\mathrm{e}}=1 / \mathrm{Q}_{\mathrm{L}} k_{\mathrm{L}}+C_{\mathrm{e}} / \mathrm{Q}_{\mathrm{L}}
$$

where $C_{e}, Q_{e}, K_{\mathrm{L}}$, and $Q_{\mathrm{L}}$ are the concentration of the adsorbate at equilibrium $(\mathrm{mg} / \mathrm{L})$, the adsorption capacity $(\mathrm{mg} / \mathrm{g})$, the Langmuir isotherm constant $(\mathrm{L} / \mathrm{mg})$, and the maximum monolayer adsorption capacity $(\mathrm{mg} / \mathrm{g})$, respectively.

Equation 2 gives the linear form of the Freundlich adsorption isotherm, where $Q_{e}$ and $C_{e}$ are the adsorption capacity $(\mathrm{mg} / \mathrm{g})$ and the concentration $(\mathrm{mg} / \mathrm{L})$ at equilibrium, while $K_{\mathrm{f}}$ and $n$ represent constants.

$$
\log Q_{\mathrm{e}}=\log K_{\mathrm{f}}+1 / n \log C_{\mathrm{e}}
$$

The isotherm constants were calculated by fitting both models to the data for $\mathrm{Pb}(\mathrm{II}), \mathrm{Cd}(\mathrm{II}), \mathrm{F}^{-}$, and $\mathrm{As}(\mathrm{V})$ separately. The plots are presented in Figures S11-S14. The fit parameters obtained are listed in Table S1. The correlation coefficient $\left(R^{2}\right)$ and the square sum of error (SSE) (the square of the difference between the experimental adsorption capacity and calculated adsorption capacity divided by the corresponding calculated adsorption capacity) were used in combination with a visual inspection of the plots to identify the best-fit isotherm model.

The uptake data can be best fitted with the Freundlich isotherm in the majority of cases, while HAP-ALG absorption can be fitted well with both models. HAP-CTS, HAP-ALG, and HAP-CMC thus appear to be multilayer systems with surface heterogeneity, as would be expected from the SEM images in Figure 1. HAP-GEL can also be described by the Langmuir model, suggesting a monolayer system; this can perhaps be attributed to the presence of different functional groups and binding sites at the surface.

2.3. Kinetic Studies. Three commonly used kinetic models, the pseudo-first-order, pseudo-second-order, and intraparticle diffusion models, were used to fit the data. The results are presented in the Supporting Information, Figures S15-S18 and Table S2. All of the systems were found to follow pseudo-second-order kinetics.

The results obtained from the adsorption isotherm and kinetic studies also indicated that HAP-CTS is the nanocomposite with the most versatile sorption properties toward all four contaminants considered in this work. Therefore, HAPCTS was subjected to further studies, in which it was loaded onto carrier materials and explored for use in real-life applications. Gravity filtration studies were also conducted using a multi-ion mixture, and regeneration studies were performed.

2.4. Characterization of Postabsorption Materials. To learn more about the uptake mechanisms, the HAP-CTS composites were analyzed after exposure to the pollutant ions, both individually and in a mixed solution (HAP-CTS-Ad).

$\mathrm{X}$-ray photoelectron spectroscopy (XPS) survey spectra for HAP-CTS and HAP-CTS treated with a multi-ion mixture of $\mathrm{Pb}(\mathrm{II}), \mathrm{Cd}(\mathrm{II}), \mathrm{As}(\mathrm{V})$, and $\mathrm{F}^{-}$(HAP-CTS-Ad) are overlaid in Figure 5. For HAP-CTS, C, N, O, P, and Ca can be observed

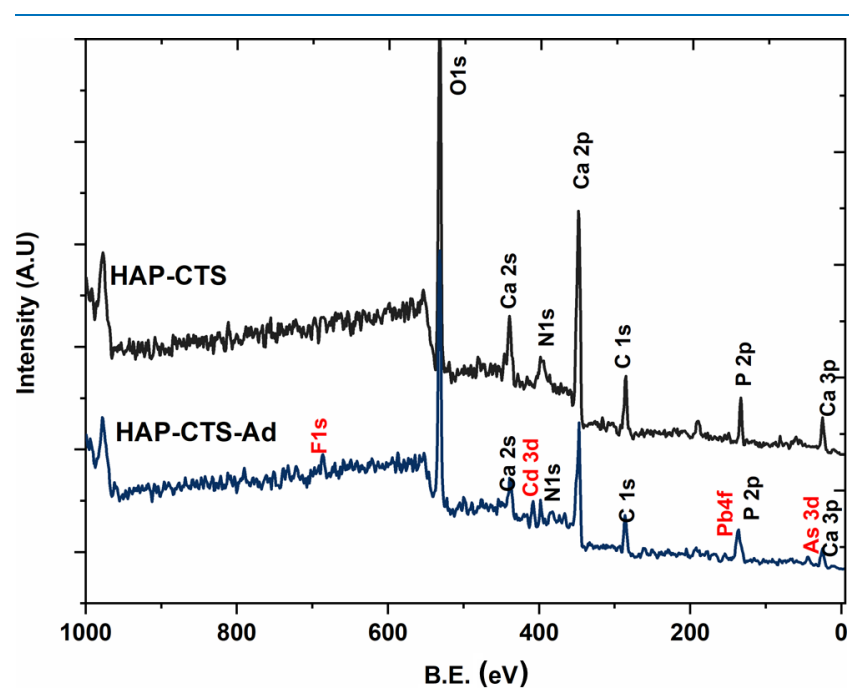

Figure 5. XPS survey spectra of (a) HAP-CTS and (b) HAP-CTS-Ad.

in the spectrum, in accordance with the chemical composition of the HAP-CTS. The survey spectrum of the HAP-CTS-Ad additionally shows distinctive lines from $\mathrm{Pb}, \mathrm{Cd}, \mathrm{As}$, and $\mathrm{F}$, consistent with the uptake discussed above. This clearly indicates the adsorption of $\mathrm{Pb}(\mathrm{II}), \mathrm{Cd}(\mathrm{II}), \mathrm{As}(\mathrm{V})$, and $\mathrm{F}^{-}$onto the surface of HAP-CTS. Using XPS data, the stoichiometric ratios of $\mathrm{Ca}$ and $\mathrm{P}$ were determined before and after the adsorption of HAP-CTS via the survey XPS spectra. The decrease of the $\mathrm{Ca} / \mathrm{P}$ ratio after the adsorption should be due to the ion exchange with $\mathrm{Pb}(\mathrm{II})$ and $\mathrm{Cd}(\mathrm{II})$, and this indicates the possibility of removing $\mathrm{Pb}$ (II) and $\mathrm{Cd}(\mathrm{II})$ by ion exchange. The analysis of $\mathrm{C} 1 \mathrm{~s}, \mathrm{O} 1 \mathrm{~s}, \mathrm{Ca} 2 \mathrm{p}$, and P $2 \mathrm{p}$ core levels were also explored and is explained in Section S.5 of the Supporting Information and Figure S19. ${ }^{64-68}$ Energy-dispersive X-ray spectroscopy analysis (EDEX) was used to identify the distribution of the elements present in both neat HAP-CTS and HAP-CTS-Ad, shown in Figure 6, and confirms uptake of the different ion species.

XRD patterns of the post-adsorption samples of HAP-CTS are given in Figure $\mathrm{S} 20 . \mathrm{Pb}(\mathrm{II}), \mathrm{Cd}(\mathrm{II})$, and $\mathrm{As}(\mathrm{V})$ adsorption has appeared to enhance the crystallinity. When $\mathrm{Pb}(\mathrm{II})$ and $\mathrm{Cd}(\mathrm{II})$ are taken up by HAP, lead pyromorphite and cadmium pyromorphite can form by ion exchange for $\mathrm{Ca}(\mathrm{II}) .{ }^{69,70}$ However, no precipitation of $\mathrm{Pb}$ (II) and $\mathrm{Cd}(\mathrm{II})$ salts with $\mathrm{PO}_{4}{ }^{3-}$ has taken place since no Bragg reflections from these phases are visible. Similarly, upon As (V) uptake, no reflections from calcium arsenate can be identified, ${ }^{71}$ and As(V) must have interacted with HAP-CTS through electrostatic forces. There is minimal difference between the patterns of HAP-CTS and HAP-CTS-F, and no increase in crystallinity is noted. This suggests that $\mathrm{F}^{-}$is not incorporated into HAP but rather chelates with chitosan or $\mathrm{Ca}^{2+}$ ions in the formulation. It also 

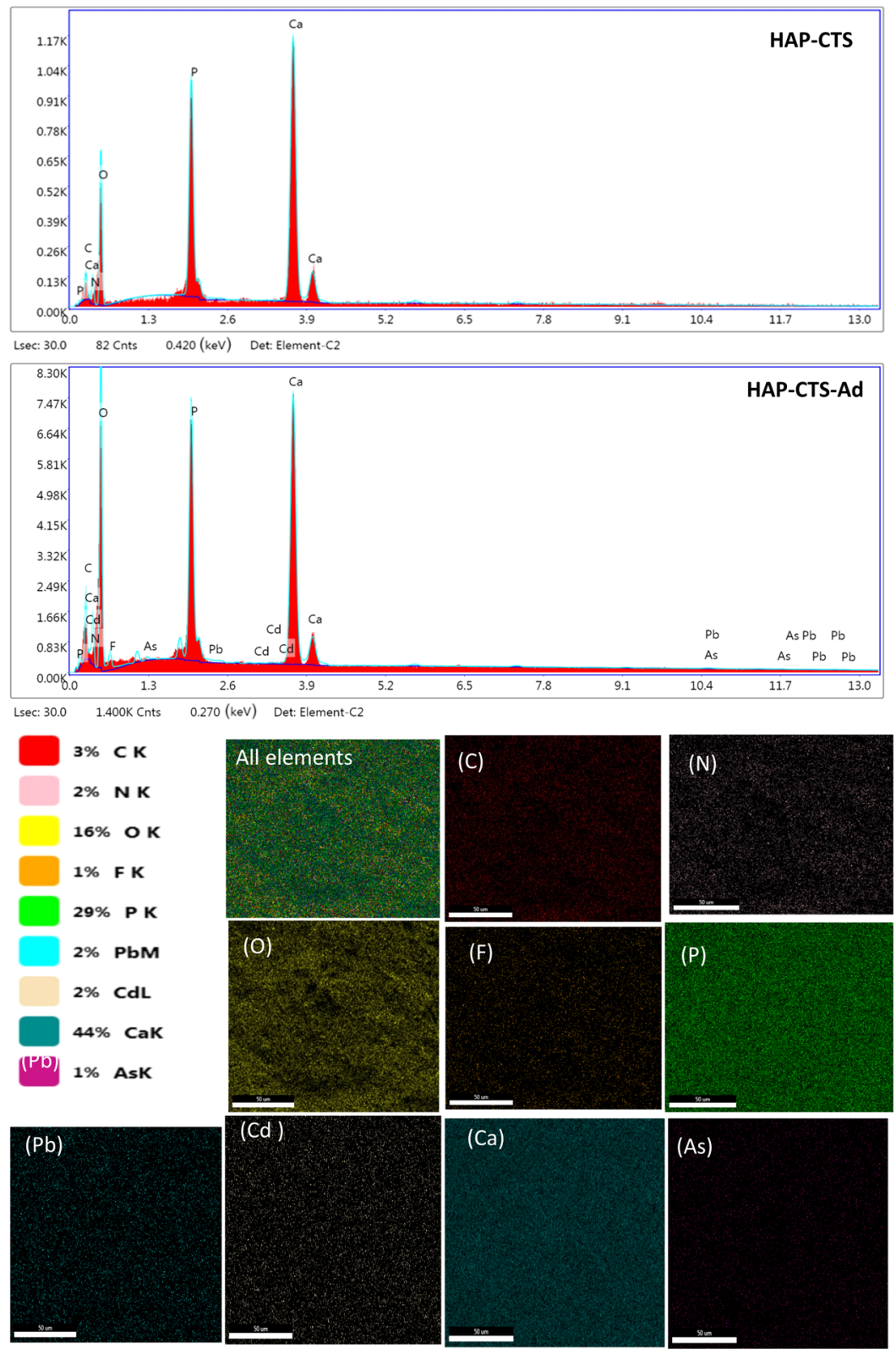

Figure 6. Element mapping of HAP-CTS-Ad and EDX spectra showing the elemental compositions of HAP-CTS and HAP-CTS-Ad.

indicates that the formation of $\mathrm{CaF}_{2}$ by precipitation of $\mathrm{Ca}$ in HAP-CTS with $\mathrm{F}^{-}$ions has not taken place since there is no evidence for $\mathrm{CaF}_{2}$ in the $\mathrm{XRD}$ data, and thus, there is no largescale precipitation of this phase. ${ }^{72-74}$ When HAP-CTS is exposed to all of the ions, the resultant pattern is a composite of the individual results seen with each pollutant.

2.5. Suggested Mechanism of Adsorption of MultiIons onto HAP-CTS. The ability of HAP-CTS to adsorb both cations and anions is very clear, based on the observations made in the adsorption studies, elemental mapping, and XPS data. Negatively charged ions $\left(\mathrm{F}^{-}\right.$and $\left.\mathrm{AsO}_{4}{ }^{3-}\right)$ get adsorbed either through an exchange process with $\mathrm{OH}^{-}$or by adhering to $\mathrm{Ca}^{2+}$ locations as depicted in Figure 7. For $\mathrm{Pb}(\mathrm{II})$ and $\mathrm{Cd}(\mathrm{II})$, ion exchange is the major mechanism underpinning uptake. In addition, these cations can also be immobilized by surface interactions with the negatively charged groups of the HAP-CTS structure.
2.6. Regeneration. HAP-CTS-Ad was subjected to regeneration studies by washing with dilute $\mathrm{HCl}$ and dilute $\mathrm{NaOH}$. The material was subjected to three adsorption cycles with a mixed solution of $10 \mathrm{ppm} \mathrm{Pb}(\mathrm{II})$ and $\mathrm{Cd}(\mathrm{II}), 1 \mathrm{ppm}$ As $(\mathrm{V})$, and $2 \mathrm{ppm} \mathrm{F}^{-}$. In each cycle, the adsorption capacity of the regenerated sample was reduced (Figure S21), ultimately to about $20-40 \%$ of the original capacity. This is expected given that the proposed uptake mechanisms lead to permanent incorporation of the pollutants into the HAP-CTS, and implies that the materials are only suitable for single-use filters.

2.7. Effect of Other lons. Pollutant ions in real-life water sources are likely to be present alongside other ions such as $\mathrm{Ca}^{2+}$ and $\mathrm{Mg}^{2+}$. The potential confounding effect of these coions was thus explored, and the results are given in Figure S22. The effect of $\mathrm{Ca}$ and $\mathrm{Mg}$ ions was investigated using 20 and 50 ppm concentrations, which is equal to hard and very hard water with a total hardness of 130 and 325 in $\mathrm{CaCO}_{3}$ equivalents, respectively. At $20 \mathrm{ppm}$, no effect can be observed 

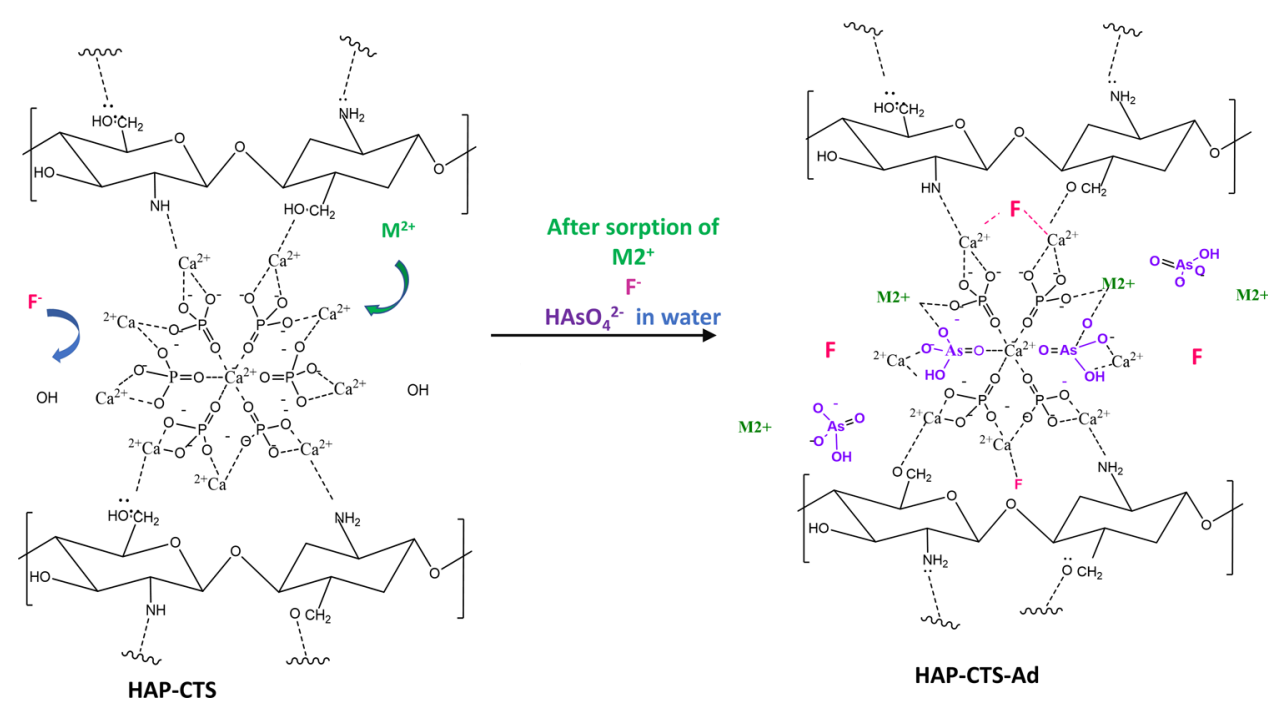

Figure 7. Proposed mechanism for the adsorption of $\mathrm{Pb}(\mathrm{II}), \mathrm{Cd}(\mathrm{II}), \mathrm{As}(\mathrm{V})$, and $\mathrm{F}^{-}$with HAP-CTS nanocomposite.

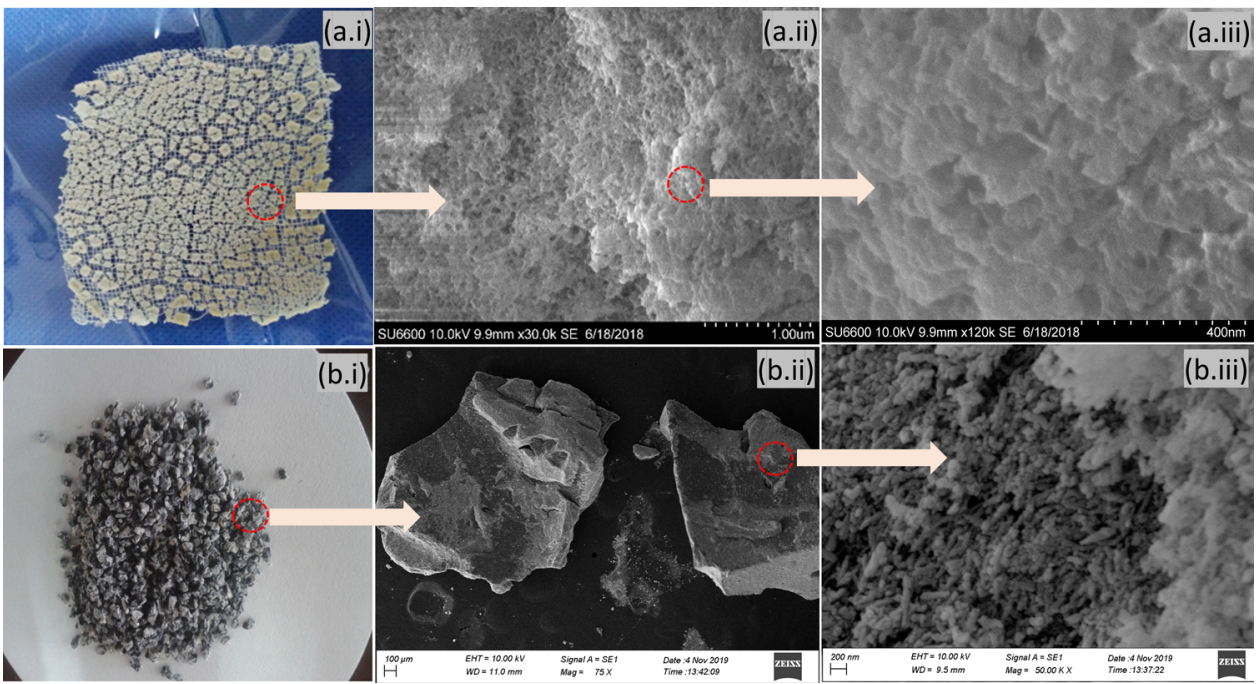

Figure 8. Morphology of the modified forms of HAP-CTS: (a) HAP-CTS-CG and (b) HAP-CTS-GAC. The magnification of the images increases moving from panel (i) to (iii).

on the adsorption of any ion. At $50 \mathrm{ppm}$ concentrations of $\mathrm{Ca}$ and $\mathrm{Mg}$, adsorption of $\mathrm{F}^{-}$and $\mathrm{As}(\mathrm{V})$ was slightly enhanced by 5 and $3 \%$ due to the precipitation of these ions with $\mathrm{Ca}$ and $\mathrm{Mg}$ at higher concentrations. Similarly, there is no reduction in the adsorption of $\mathrm{Pb}(\mathrm{II})$ and $\mathrm{Cd}(\mathrm{II})$ at $20 \mathrm{ppm} \mathrm{Ca} / \mathrm{Mg}$, but there is a ca. $10 \%$ reduction at $20 \mathrm{ppm}$. No reduction in uptake performance was observed in the presence of nitrate and nitrite ions.

2.8. HAP-CTS-Loaded Matrices. After analyzing the adsorption data, it was found that HAP-CTS was the optimal polymer composite, showing the ability to remove both cations and anions from water. Therefore, this composite was integrated with other matrices to develop devices for water purification since powder forms are not generally favorable in real applications. For this purpose, we selected cotton gauze and granular activated carbon (GAC) as possible matrices. The resultant materials were named HAP-CTS-CG and HAP-CTSGAC. Figure 8 depicts the distribution of HAP-CTS in a gauze matrix at three different magnifications. All these images indicate a uniform distribution of HAP-CTS and good porosity. When HAP-CTS was coated on GAC, a uniform coverage was not obtained (Figure $8 \mathrm{~b}$ ).

2.9. Gravity Filtration Studies. Gravity filtration studies were conducted for HAP-CTS, HAP-CTS-GAC, and HAPCTS-CG, using gravity columns with $1 \mathrm{~cm}$ diameter to investigate the composites' use in real-life applications using a mixture of ions. The initial concentration of $\mathrm{F}^{-}$was maintained at $2 \mathrm{ppm}$, as the commonly prevailing concentration in the groundwater of Sri Lanka is around $1.5-2.0 \mathrm{ppm} .{ }^{6,8}$ The initial concentrations of $\mathrm{As}(\mathrm{V}), \mathrm{Pb}(\mathrm{II})$, and $\mathrm{Cd}(\mathrm{II})$ were maintained at $50 \mathrm{ppb}$, the maximum levels reported in the $\mathrm{CKDu}$ prominent areas of Sri Lanka. 3,7,8,75 Breakthrough capacities were calculated by considering $0.5 \mathrm{ppm}$ as the safe limit for $\mathrm{F}^{-}$ and $5 \mathrm{ppb}$ for $\mathrm{As}(\mathrm{V}), \mathrm{Pb}(\mathrm{II})$, and $\mathrm{Cd}(\mathrm{II})$, according to the WHO standards. ${ }^{76}$ Experiments involved passing the aforementioned ion mixture through the gravity column at a rate of $10 \mathrm{~mL} / 30 \pm 5 \mathrm{~s}$. The breakthrough point is defined as the eluted volume at which the WHO limits are breached. The breakthrough curves for $\mathrm{Cd}(\mathrm{II}), \mathrm{Pb}(\mathrm{II}), \mathrm{AS}(\mathrm{V})$, and $\mathrm{F}^{-}$are presented in Figure 9. HAP-CTS showed the highest breakthrough volume for all the contaminant ions. The 

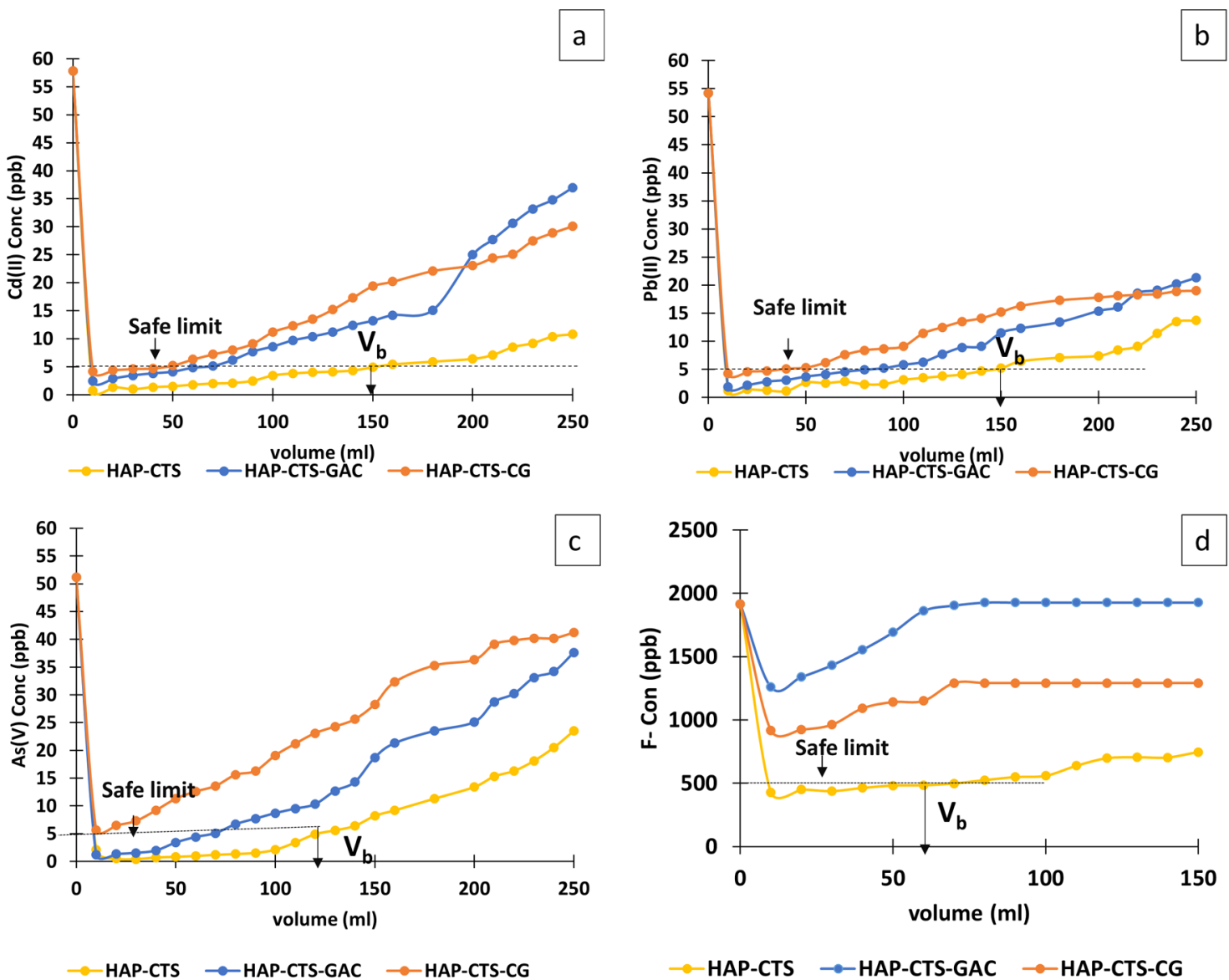

Figure 9. Breakthrough curves for (a) Cd(II), (b) $\mathrm{Pb}(\mathrm{II}),(\mathrm{c}) \mathrm{As}(\mathrm{V})$, and (d) $\mathrm{F}^{-}$determined from gravity filtration studies with HAP-CTS powder, HAP-CTS-GAC, and HAP-CTS-CG. $V_{\mathrm{b}}$ : breakthrough volume.

calculated breakthrough volumes for HAP-CTS with $\mathrm{Pb}(\mathrm{II})$, $\mathrm{Cd}(\mathrm{II})$, As(V), and $\mathrm{F}^{-}$were 3000, 3000, 2600, and $2000 \mathrm{~mL} / \mathrm{g}$ respectively. As far as the safe limit of $\mathrm{F}^{-}$is concerned, only HAP-CTS reached the required target.

The results of the adsorption studies and the gravity filtration studies obtained in this study were compared with the other HAP-based nanocomposites in the literature by considering the initial concentration, $\mathrm{pH}$, isotherm, and kinetic models (Table 1).

Table 1 summarizes the adsorption properties of previously reported HAP-based nanocomposites toward $\mathrm{Pb}(\mathrm{II}), \mathrm{Cd}(\mathrm{II})$, $\mathrm{F}^{-}$, and $\mathrm{As}(\mathrm{V})$. There are significant variations in the adsorption properties depending on the reaction conditions. Many studies have been conducted to study $\mathrm{F}^{-}, \mathrm{Pb}(\mathrm{II})$, and $\mathrm{Cd}(\mathrm{II})$ adsorption, but studies for the adsorption of As(V) are few in number. The different experimental setups used make it hard to compare the different formulations. However, the equilibrium time obtained in this work is comparatively low, and HAP-CTS gives good uptake with a low contact time for $\mathrm{Cd}(\mathrm{II}), \mathrm{F}^{-}$, and $\mathrm{As}(\mathrm{V})$. In $\mathrm{F}^{-}$adsorption, the highest adsorption capacity of $98.8 \mathrm{mg} / \mathrm{g}$ is reported for Al-HAP using an initial concentration of $200 \mathrm{ppm} .^{78}$ This is higher than the values obtained in this work, in part likely due to the fact that the literature protocol uses a higher initial $\mathrm{F}^{-}$ concentration than used here in addition to the high affinity of $\mathrm{Al}$ for fluorides. Comparison of the breakthrough capacities in gravity filtration studies is not possible since the literature does not report the densities of the materials used. However, what is clear is that our systems perform at least on par with those previously reported, and HAP-CTS acts as a versatile multi-ion absorbent.

\section{CONCLUSIONS}

Four HAP biopolymer nanocomposites with chitosan, carboxymethyl cellulose, sodium alginate, and gelatin were successfully synthesized and used for the adsorption of $\mathrm{Pb}$ (II), $\mathrm{Cd}(\mathrm{II}), \mathrm{As}(\mathrm{V})$, and $\mathrm{F}^{-}$from water. The structure, morphology, and adsorption properties of these four nanocomposites were compared, and HAP-CTS was identified as the most versatile sorbent toward all four ions. Therefore, HAP-CTS was further modified for use in filters by combining it with gauze and GAC. Gravity filtration studies indicated that the powder form of HAP-CTS is the best sorbent, giving the highest breakthrough capacities of 3000, 3000, 2600, and $2000 \mathrm{~mL} /$ $\mathrm{g}$ for $\mathrm{Pb}(\mathrm{II}), \mathrm{Cd}(\mathrm{II}), \mathrm{As}(\mathrm{V})$, and $\mathrm{F}^{-}$, respectively. The main mechanism of cation removal from solution was found to be via ion exchange with $\mathrm{Ca}^{2+}$, while anions were removed through binding with $\mathrm{Ca}^{2+}$ sites and by exchange with replaceable $\mathrm{OH}^{-}$ions.

\section{EXPERIMENTAL SECTION}

4.1. Materials. All chemicals were of analytical grade and used without further purification. Ammonium hydroxide [ $\left.\mathrm{NH}_{4} \mathrm{OH}\right]$ solution (25\%, Sigma-Aldrich), calcium nitrate tetrahydrate $\left[\mathrm{Ca}\left(\mathrm{NO}_{3}\right)_{2} \cdot 4 \mathrm{H}_{2} \mathrm{O}\right]$ (98\%, Sigma-Aldrich), and diammonium hydrogen orthophosphate $\left[\left(\mathrm{NH}_{4}\right)_{2} \mathrm{HPO}_{4}\right](98 \%$, Sigma-Aldrich) were used to synthesize neat HAP. Chitosan 


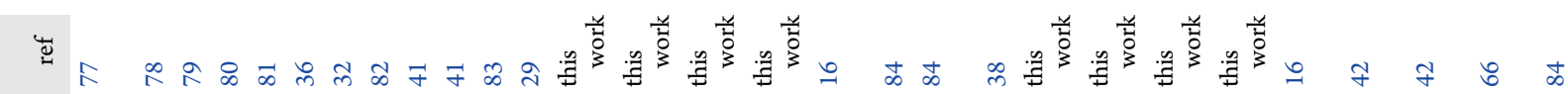

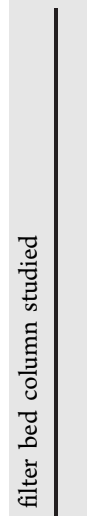

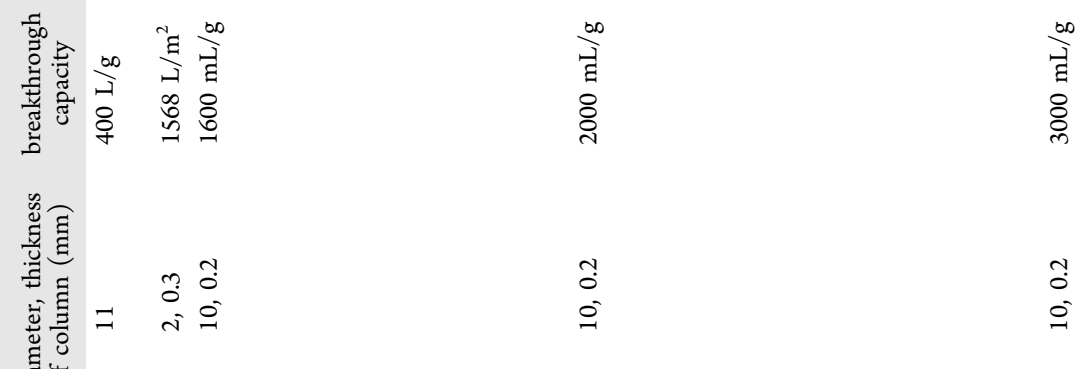

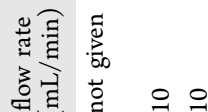

$\stackrel{2}{\varrho}$

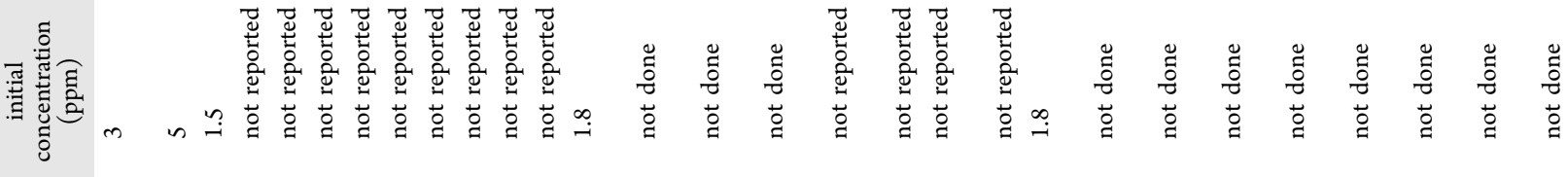

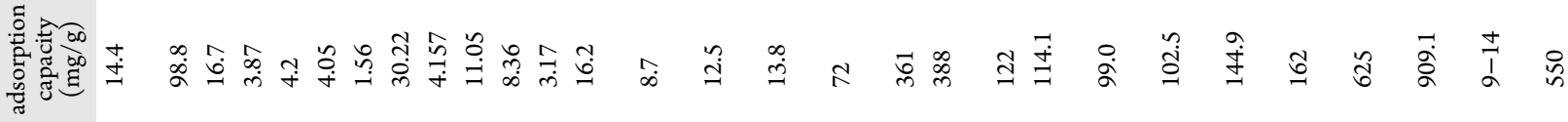

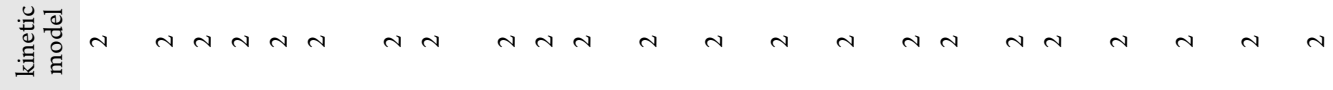

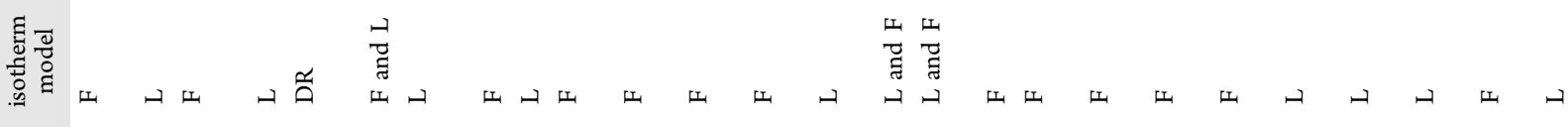

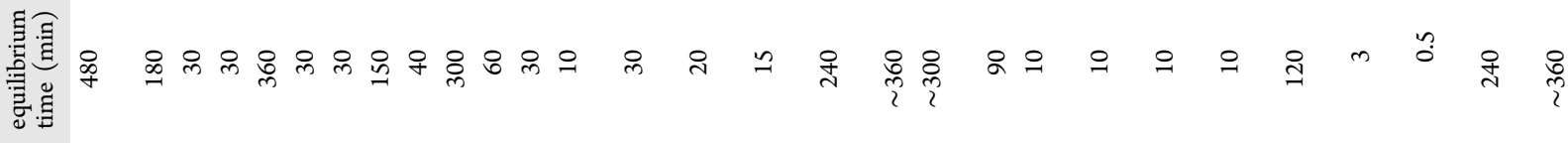

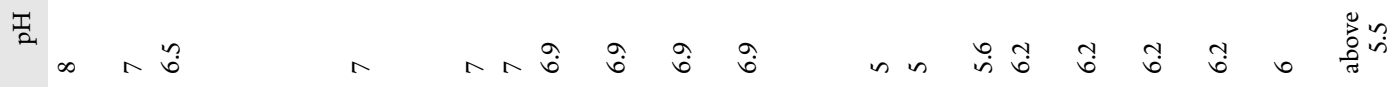

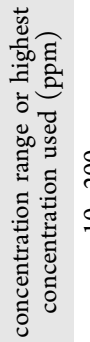

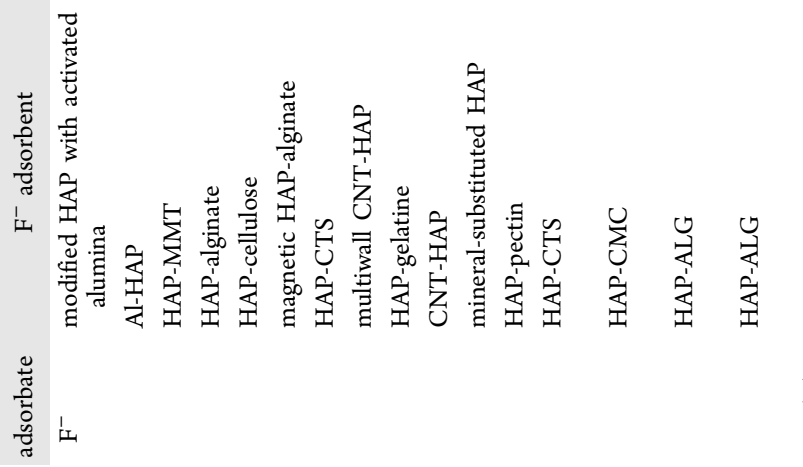

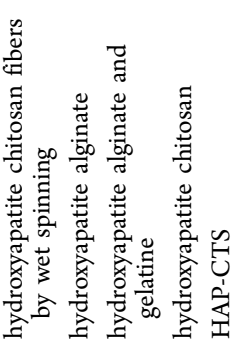

$\widehat{\Xi}$

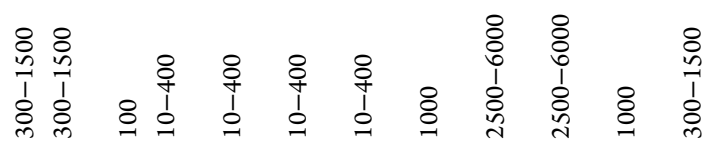




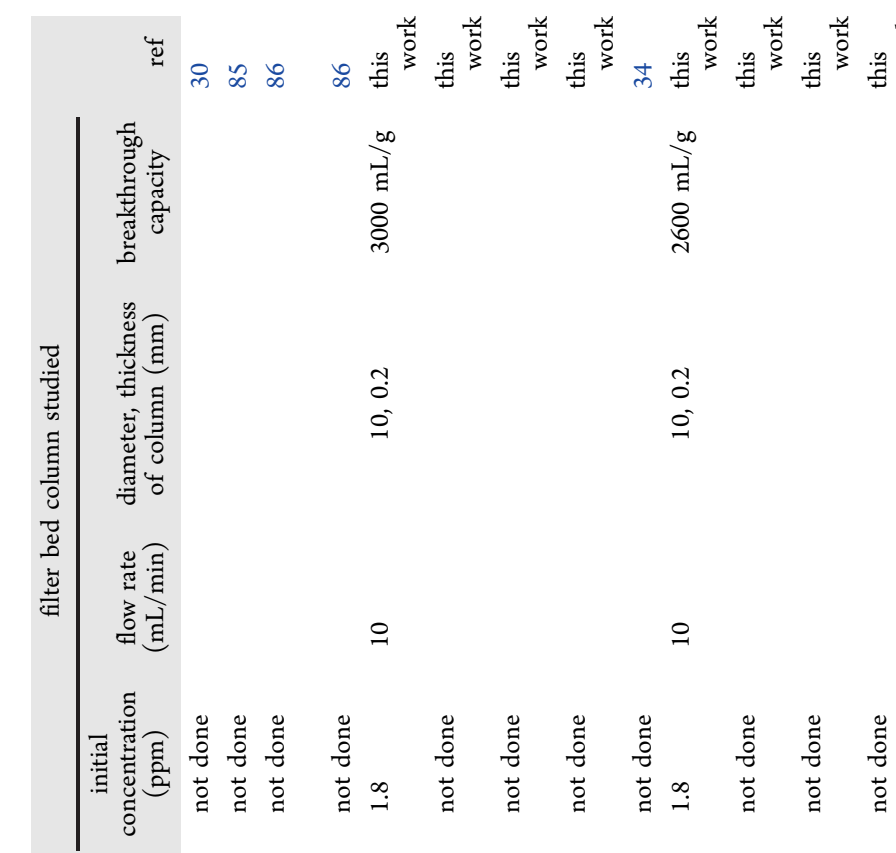

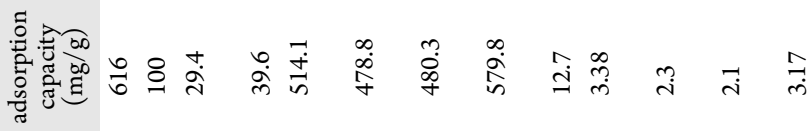

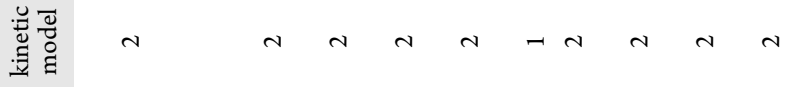

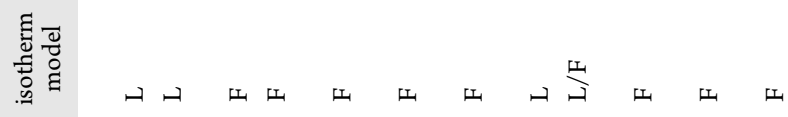

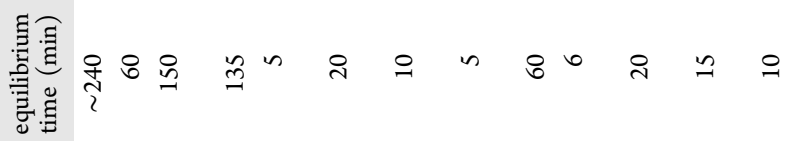

空

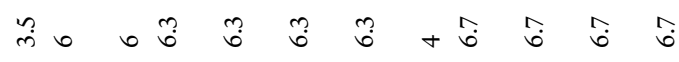

总

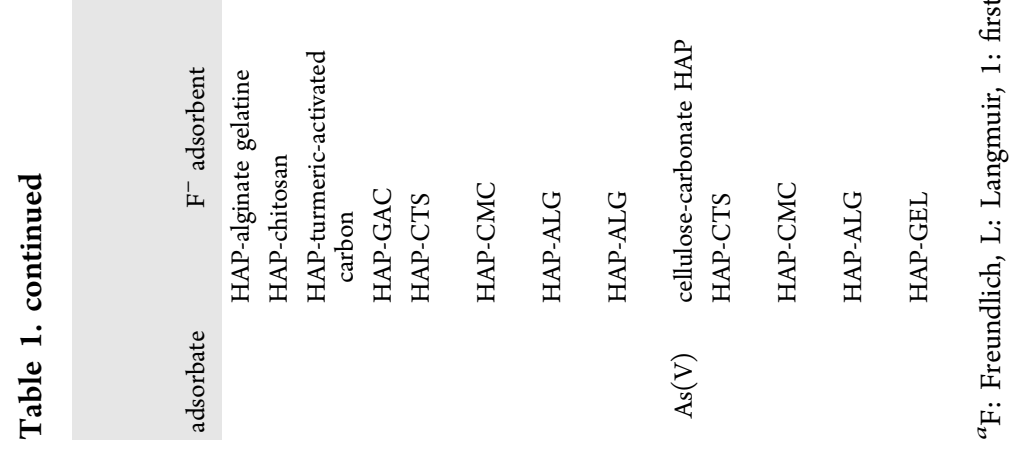


(85\%, deacetylated medium molecular weight, Sigma-Aldrich), carboxymethyl cellulose (low viscosity, Sigma-Aldrich), sodium alginate (low viscosity, Sigma-Aldrich), and gelatin type B (medium bloom, SRL) were used in the synthesis process of HAP-biopolymer nanocomposites. Cadmium nitrate (Sigma-Aldrich), lead nitrate (Merck), sodium fluoride (99.5\%, Merck), and sodium arsenate (99\%, Merck) were used to prepare the pollutant stock solutions.

4.2. Synthesis of HAP Biopolymer Nanocomposites. Synthesis of HAP was carried out according to the literature. ${ }^{66}$ HAP-based nanocomposites were synthesized by in situ precipitation. $\left(\mathrm{NH}_{4}\right)_{2} \mathrm{HPO}_{4}$ was mixed with a polymer solution $(2 \%, \mathrm{w} / \mathrm{v})$ at predetermined ratios, and vigorously stirred until a homogeneous solution was formed. $\mathrm{Ca}\left(\mathrm{NO}_{3}\right)_{2} \cdot 4 \mathrm{H}_{2} \mathrm{O}$ was added dropwise into the solution to give a $\mathrm{Ca} / \mathrm{P}$ ratio of 1.67 , at $60{ }^{\circ} \mathrm{C}$ with vigorous stirring. During this process, the $\mathrm{pH}$ was kept at 10 with dropwise addition of $\mathrm{NH}_{4} \mathrm{OH}(5 \mathrm{M})$. The mixture was vigorously stirred for $\sim 3 \mathrm{~h}$ at room temperature and aged for $24 \mathrm{~h}$ at room temperature. The resultant precipitate was washed with distilled water until its $\mathrm{pH}$ became neutral and the product was separated by centrifugation. The resultant solid was oven-dried at $40{ }^{\circ} \mathrm{C}$ until a constant weight was obtained.

4.3. Incorporation of HAP-CTS into Filtration Matrix. HAP-CTS was amalgamated with granular activated carbon (GAC) and cotton gauze (CG) at a weight ratio of $1: 1$. Then, the materials were oven-dried at $60{ }^{\circ} \mathrm{C}$.

4.4. Characterization. The surface morphology of the four HAP-biopolymer nanocomposites was studied using a Hitachi SU6600 field emission scanning electron microscope (SEM). Fourier transform infrared (FTIR) spectra were collected on an AVATAR-320 instrument (Thermo Nicolet) in the wavenumber range between 500 and $4000 \mathrm{~cm}^{-1}$. X-ray diffraction analysis was conducted using a Rigaku SmartLab $\mathrm{X}$-ray powder diffractometer using $\mathrm{Cu} \mathrm{K} \alpha$ radiation $(\lambda=0.154$ $\mathrm{nm})$ over a $2 \theta$ range of $2-80^{\circ}$, with a step size of $0.02^{\circ}$. Thermogravimetric analysis was carried out using an SDT Q 600 analyzer in the temperature range from room temperature to $800{ }^{\circ} \mathrm{C}$ under air. Brunauer-Emmett-Teller (BET) analysis was performed using an automated gas sorption analyzer (Autosorb iQ-MP (1 stat), Viton).

4.5. Adsorption Studies. 4.5.1. Elemental Concentrations. The concentrations of $\mathrm{Pb}(\mathrm{II}), \mathrm{Cd}(\mathrm{II})$, and $\mathrm{As}(\mathrm{V})$ before and after adsorption were analyzed using a GBC $932 \mathrm{AB}$ atomic adsorption spectrometer (AAS) with necessary dilutions. Low ion concentrations ( $\mathrm{ppb}$ level) were analyzed using an Agilent 4219 Microwave Plasma Atomic Emission Spectrophotometer (MP-AES). $\mathrm{F}^{-}$concentrations were analyzed using an $\mathrm{F}^{-}$ion-selective electrode by Hanna Instruments.

4.5.2. Effect of Time on Adsorption. The adsorption capacity for $\mathrm{Pb}(\mathrm{II}), \mathrm{Cd}(\mathrm{II}), \mathrm{As}(\mathrm{V})$, and $\mathrm{F}^{-}$was investigated over 60 min using initial concentrations of 1900,400, 1, and 40 ppm, respectively. Experiments were carried out with $20 \mathrm{~mL}$ volume and $0.04 \mathrm{~g}$ of the absorbent at room temperature (27 $\pm 1{ }^{\circ} \mathrm{C}$ ) with continuous stirring at a rate of $200 \mathrm{rpm}$ using a horizontal shaker.

4.5.3. Effect of $\mathrm{pH}$ on Adsorption. To identify the adsorption properties at different $\mathrm{pH}$ levels, studies were carried out with $\mathrm{Pb}(\mathrm{II}), \mathrm{Cd}(\mathrm{II}), \mathrm{F}^{-}$, and $\mathrm{As}(\mathrm{V})$ separately over the $\mathrm{pH}$ range $3-11$. Solutions were prepared as detailed in Section 4.5.3, except that the $\mathrm{pH}$ levels were adjusted using dilute $\mathrm{HCl}$ and dilute $\mathrm{NaOH}$.
4.5.4. Isotherm Studies. Adsorption studies were performed in polypropylene containers at room temperature $\left(27 \pm 1{ }^{\circ} \mathrm{C}\right)$ with continuous stirring at a rate of $200 \mathrm{rpm}$ using a horizontal shaker. The solutions were agitated until they reached the predetermined analysis time, when they were immediately filtered and the residual concentrations of the ions in the solution were analyzed with necessary dilutions.

Adsorption studies for $\mathrm{Pb}$ (II) and $\mathrm{Cd}$ (II) were carried out in the concentration ranges of $112-1540$ and $10-400 \mathrm{ppm}$, respectively, at a fixed volume of $20 \mathrm{~mL}$ with $0.04 \mathrm{~g}$ of HAP composite. A stock solution of fluoride (1000 ppm) was prepared using $\mathrm{NaF}$ and deionized water. It was then diluted to the desired concentrations. Batch adsorption studies were carried out using $20 \mathrm{~mL}$ of the fluoride solution and $0.04 \mathrm{~g}$ of the absorbent, varying the fluoride concentration from 10 to 40 ppm. A stock solution of arsenate $(50 \mathrm{ppm})$ was prepared using $\mathrm{Na}_{2} \mathrm{HAsO}_{4}$ and deionized water. Isotherm studies were carried out using $20 \mathrm{~mL}$ of aliquots at concentrations from 600 to $16000 \mathrm{ppb}$ with $0.04 \mathrm{~g}$ of the adsorbent.

4.6. Kinetic Studies. Kinetic studies of $\mathrm{Pb}(\mathrm{II}), \mathrm{Cd}(\mathrm{II})$, $\mathrm{As}(\mathrm{V})$, and $\mathrm{F}^{-}$adsorption were carried out at initial concentrations of 1900,400,1, and $40 \mathrm{ppm}$, respectively, using $0.04 \mathrm{~g}$ of HAP composite and $20 \mathrm{~mL}$ of the target solution for 2 h. $^{79}$

4.7. Detailed Analysis of HAP-CTS. HAP-CTS (60\%) was subjected to adsorption studies using multi-ion mixture containing 2 ppm $\mathrm{F}^{-}$and $50 \mathrm{ppb}$ of $\mathrm{Pb}(\mathrm{II}), \mathrm{Cd}(\mathrm{II})$, and $\mathrm{As}(\mathrm{V})$. HAP-CTS samples were exposed to surface analysis using Xray photoelectron spectroscopy (XPS) and energy-dispersive $\mathrm{X}$-ray spectroscopy (EDEX) before and after the adsorption process.

For XPS, a Thermo Fisher Scientific UK instrument was employed, with an X-ray source of $\mathrm{Al} \mathrm{K} \alpha(1486.6 \mathrm{eV})$ attached to an ultra-high vacuum chamber. Survey XPS spectra with high pass energy (PE) and core-level spectra with low PE were performed in the constant analyzer energy mode with a pass energy of 50-200 eV, energy step of $0.1 \mathrm{eV}$, and scan numbers of 3 and 10, respectively. In this experiment, the base pressure in the ultra-high vacuum (UHV) chamber was lower than $2 \times$ $10^{-8} \mathrm{~Pa}$. The X-ray power was kept at $100 \mathrm{~W}$ to minimize radiation damage and the surface charge effect. The samples were neutralized using an electron flood gun. The ratio of intensities of photoelectron peaks of $\mathrm{Ca} 2 \mathrm{p}$ and $\mathrm{P} 2 \mathrm{p}$ peaks were calculated as explained in Section S.6 in the Supporting Information. ${ }^{53,54}$ EDEX was carried out using a $\mathrm{Z} 1$ analyzer.

4.8. Gravity Filtration Studies. Gravity filtration studies were conducted for HAP-CTS. A mixture was prepared with $50 \mathrm{ppb}$ of $\mathrm{Pb}(\mathrm{II}), \mathrm{Cd}(\mathrm{II})$, and $\mathrm{As}(\mathrm{V})$, and $2 \mathrm{ppm}$ of $\mathrm{F}^{-}$was to mimic the groundwater in CKDu affected areas in Sri Lanka. The mixed ion solution was passed through a column with a diameter of $1 \mathrm{~cm}$, across a filter bed prepared with $50 \mathrm{mg}$ of the adsorbent deposited on $50 \mathrm{mg}$ of a cotton bed, at a rate of $10 \mathrm{~mL}$ per $30 \pm 5 \mathrm{~s}$. The breakthrough capacity was calculated using the volume of the solution that could pass through before the $\mathrm{F}^{-}$concentration exceeded $0.5 \mathrm{ppm}$. For $\mathrm{Pb}(\mathrm{II})$, $\mathrm{Cd}(\mathrm{II})$, and $\mathrm{As}(\mathrm{V}), 5 \mathrm{ppb}$ was considered as the permissible level in accordance with WHO standards.

\section{ASSOCIATED CONTENT}

\section{S1 Supporting Information}

The Supporting Information is available free of charge at https://pubs.acs.org/doi/10.1021/acsomega.1c00316. 
Optimization of the synthesis of HAP biopolymer nanocomposites; BET analysis; adsorption and kinetic data and the plots; thermogravimetric analysis; analysis of HAP-CTS post-adsorption; and additional experimental data (XPS, BET, regeneration, and effect of other ions) (PDF)

\section{AUTHOR INFORMATION}

\section{Corresponding Author}

Rohini M. de Silva - Centre for Advanced Materials and Devices (CAMD), Department of Chemistry, University of Colombo, Colombo 00300, Sri Lanka; ๑ orcid.org/00000003-0955-6366; Email: rohini@chem.cmb.ac.lk

\section{Authors}

M. Shanika Fernando - Centre for Advanced Materials and Devices (CAMD), Department of Chemistry, University of Colombo, Colombo 00300, Sri Lanka

A. K. D. V. K. Wimalasiri - Centre for Advanced Materials and Devices (CAMD), Department of Chemistry, University of Colombo, Colombo 00300, Sri Lanka

Karolina Dziemidowicz - UCL School of Pharmacy, University College London, London WCIN IAX, U.K.

Gareth R. Williams - UCL School of Pharmacy, University College London, London WCIN 1AX, U.K.; ๑ orcid.org/ 0000-0002-3066-2860

K. R. Koswattage - Faculty of Technology, Sabaragamuwa University of Sri Lanka, Belihuloya 70140, Sri Lanka

D. P. Dissanayake - Centre for Advanced Materials and Devices (CAMD), Department of Chemistry, University of Colombo, Colombo 00300, Sri Lanka; ๑ orcid.org/00000002-6213-5782

K. M. Nalin de Silva - Centre for Advanced Materials and Devices (CAMD), Department of Chemistry, University of Colombo, Colombo 00300, Sri Lanka; ๑ orcid.org/00000003-3219-3233

Complete contact information is available at:

https://pubs.acs.org/10.1021/acsomega.1c00316

\section{Author Contributions}

The manuscript was written through the contributions of all authors. All authors have given approval to the final version of the manuscript.

\section{Notes}

The authors declare no competing financial interest.

\section{ACKNOWLEDGMENTS}

The authors gratefully acknowledge the National Research Council Sri Lanka for financial support provided under Grant NRC TO 16-18. The support given by the academic and technical staff of the Department of Chemistry, Faculty of Science, University of Colombo, is highly appreciated.

\section{REFERENCES}

(1) Yang, C. Y.; Cheng, M. F.; Tsai, S. S.; Hung, C. F. Fluoride in Drinking Water and Cancer Mortality in Taiwan. Environ. Res. 2000, 82, 189-193.

(2) Qiao, J.; Zhu, Y.; Jia, X.; Shao, M.; Niu, X.; Liu, J. Distributions of Arsenic and Other Heavy Metals, and Health Risk Assessments for Groundwater in the Guanzhong Plain Region of China. Environ. Res. 2020, 181, No. 108957.
(3) Dharmaratne, R. W. Fluoride in Drinking Water and Diet: The Causative Factor of Chronic Kidney Diseases in the North Central Province of Sri Lanka. Environ. Health Prev. Med. 2015, 20, 237-242.

(4) Choubisa, S. L.; Choubisa, L.; Choubisa, D. K. Endemic Fluorosis in Rajasthan. Indian J. Environ. Health 2001, 43, 177-189. (5) Drahansky, M.; Paridah, M.; Moradbak, A.; Mohamed, A.; Owolabi, F. A. T.; Asniza, M.; Abdul Khalid, S. H. Investigation of Electrochemical Pitting Corrosion by Linear Sweep Voltammetry: A Fast and Robust Approach; Intech, 2016; p 13.

(6) Chandrajith, R.; Padmasiri, J. P.; Dissanayake, C. B.; Prematilaka, K. M. Spatial Distribution of Fluoride in Groundwater of Sri Lanka. J. Natl. Sci. Found. Sri Lanka 2012, 40, 303-309.

(7) Dharma-wardana, M. W. C.; Amarasiri, S. L.; Dharmawardene, N.; Panabokke, C. R. Chronic Kidney Disease of Unknown Aetiology and Ground-Water Ionicity: Study Based on Sri Lanka. Environ. Geochem. Health 2015, 37, 221-231.

(8) Wickramarathna, S.; Balasooriya, S.; Diyabalanage, S.; Chandrajith, R. Tracing Environmental Aetiological Factors of Chronic Kidney Diseases in the Dry Zone of Sri Lanka-A Hydrogeochemical and Isotope Approach. J. Trace Elem. Med. Biol. 2017, 44, 298-306.

(9) Dissanayake, C. B.; Chandrajith, R. Groundwater Fluoride as a Geochemical Marker in the Etiology of Chronic Kidney Disease of Unknown Origin in Sri Lanka. Ceylon J. Sci. 2017, 46, 3.

(10) Gautam, P. K.; Gautam, R. K.; Banerjee, S.; Chattopadhyaya, M. C.; Pandey, J. D. Heavy Metals in the Environment: Fate, Transport, Toxicity and Remediation Technologies. In Heavy Metals: Sources, Toxicity and Remediation Techniques; Nova Science Publishers, Inc., 2016; Vol. 14, pp 101-130.

(11) Santhosh, C.; Velmurugan, V.; Jacob, G.; Kwan, S.; Nirmala, A.; Bhatnagar, A. Role of Nanomaterials in Water Treatment Applications: A Review. Chem. Eng. J 2016, 306, 1116-1137.

(12) Amin, M. T.; Alazba, A. A.; Manzoor, U. A Review of Removal of Pollutants from Water/Wastewater Using Different Types of Nanomaterials. Adv. Mater. Sci. Eng. 2014, 2014, No. 825910.

(13) Costa, W. D.; da Silva Bento, A. M.; de Araújo, J. A. S.; Menezes, J. M. C.; da Costa, J. G. M.; da Cunha, F. A. B.; Coutinho, H. D. M.; de Paula Filho, F. J.; Pereira Teixeira, R. N. Removal of Copper(II) Ions and Lead(II) from Aqueous Solutions Using Seeds of Azadirachta Indica A. Juss as Bioadsorvent. Environ. Res. 2020, 183, No. 109213.

(14) Manatunga, D. C.; Godakanda, V. U.; de Silva, R. M.; de Silva, K. M. N. Recent Developments in the Use of Organic-Inorganic Nanohybrids for Drug Delivery. Wiley Interdiscip. Rev. Nanomed. Nanobiotechnol. 2020, 12, No. e1605.

(15) Ibrahim, M.; Labaki, M.; Giraudon, J. M.; Lamonier, J. F. Hydroxyapatite, a Multifunctional Material for Air, Water and Soil Pollution Control: A Review. J. Hazard. Mater. 2020, 383, No. 121139.

(16) Park, S.; Gomez-Flores, A.; Chung, Y. S.; Kim, H. Removal of Cadmium and Lead from Aqueous Solution by Hydroxyapatite/ Chitosan Hybrid Fibrous Sorbent: Kinetics and Equilibrium Studies. J. Chem. 2015, 2015, No. 396290.

(17) Sternitzke, V.; Johnson, C. A. Adsorption of Fluoride on Synthetic Hydroxyapatite. Geochim. Cosmochim. Acta 2009, 73, A1273.

(18) Jiménez-Reyes, M.; Solache-Ríos, M. Sorption Behavior of Fluoride Ions from Aqueous Solutions by Hydroxyapatite. J. Hazard. Mater. 2010, 180, 297-302.

(19) Sternitzke, V.; Kaegi, R.; Audinot, J.-N.; Lewin, E.; Hering, J. G.; Johnson, C. A. Uptake of Fluoride from Aqueous Solution on Nano-Sized Hydroxyapatite: Examination of a Fluoridated Surface Layer. Environ. Sci. Technol. 2012, 46, 802-809.

(20) Zhang, G.; Qu, R.; Sun, C.; Ji, C.; Chen, H.; Wang, C.; Niu, Y. Adsorption for Metal Ions of Chitosan Coated Cotton Fiber. J. Appl. Polym. Sci. 2008, 110, 2321-2327.

(21) Nechita, P. Applications of Chitosan in Wastewater Treatment. In Biological Activities and Application of Marine Polysaccharides; 
Shalaby, E. A., Ed.; Intech Open: London, 2017; pp 210-223, DOI: $10.5772 / 65289$.

(22) Bhatnagar, A.; Sillanpää, M. Applications of Chitin- and Chitosan-Derivatives for the Detoxification of Water and Wastewater-A Short Review. Adv. Colloid Interface Sci. 2009, 152, 26-38.

(23) Charpentier, T. V. J.; Neville, A.; Lanigan, J. L.; Barker, R.; Smith, M. J.; Richardson, T. Preparation of Magnetic Carboxymethylchitosan Nanoparticles for Adsorption of Heavy Metal Ions. ACS Omega 2016, 1, 77-83.

(24) Wang, J.; Liu, M.; Duan, C.; Sun, J.; Xu, Y. Preparation and Characterization of Cellulose-Based Adsorbent and Its Application in Heavy Metal Ions Removal. Carbohydr. Polym. 2019, 206, 837-843.

(25) Uva, M.; Tambasco, M.; Grassi, G.; Corsi, I.; Protano, G.; Atrei, A. Carboxymethylcellulose Hydrogels Cross-Linked with Magnetite Nanoparticles for the Removal of Organic and Inorganic Pollutants from Water. J. Environ. Chem. Eng. 2017, 5, 3632-3639.

(26) Saber-Samandari, S.; Saber-Samandari, S.; Heydaripour, S.; Abdouss, M. Novel Carboxymethyl Cellulose Based Nanocomposite Membrane: Synthesis, Characterization and Application in Water Treatment. J. Environ. Manage. 2016, 166, 457-465.

(27) Hashem, A.; Elhmmali, M. M. Modification of Sodium Alginate for the Removal of Cd(II) from Aqueous Solutions. Polym.-Plast. Technol. Eng. 2006, 45, 707-712.

(28) Ge, Y.; Qin, L.; Li, Z. Lignin Microspheres: An Effective and Recyclable Natural Polymer-Based Adsorbent for Lead Ion Removal. Mater. Des. 2016, 95, 141-147.

(29) Raghav, S.; Sapna; Kumar, D. Cubical-Shaped Rods of PectinHydroxyapatite Composite for Adsorption Studies of Fluoride by Statistical Method and Adsorption Experiments. ACS Omega 2018, 3, 9675-9688.

(30) Thakur, S.; Govender, P. P.; Mamo, M. A.; Tamulevicius, S.; Thakur, V. K. Recent Progress in Gelatin Hydrogel Nanocomposites for Water Purification and Beyond. Vacuum 2017, 146, 396-408.

(31) Manatunga, D. C.; Godakanda, V. U.; Herath, H. M. L. P. B.; De Silva, R. M.; Yeh, C. Y.; Chen, J. Y.; De Silva, A. A. A.; Rajapaksha, S.; Nilmini, R.; De Silva, K. M. N. Nanofibrous Cosmetic Face Mask for Transdermal Delivery of Nano Gold: Synthesis, Characterization, Release and Zebra Fish Employed Toxicity Studies: Nanofibrous Mask for Delivery of Gold. R. Soc. Open Sci. 2020, 7, No. 201266.

(32) Sundaram, C. S.; Viswanathan, N.; Meenakshi, S. Uptake of Fluoride by Nano-Hydroxyapatite/Chitosan, a Bioinorganic Composite. Bioresour. Technol. 2008, 99, 8226-8230.

(33) Poinern, G. E. J.; Ghosh, M. K.; Ng, Y. J.; Issa, T. B.; Anand, S.; Singh, P. Defluoridation Behavior of Nanostructured Hydroxyapatite Synthesized through an Ultrasonic and Microwave Combined Technique. J. Hazard. Mater. 2011, 185, 29-37.

(34) Islam, M.; Chandra, P.; Patel, R. Arsenate Removal from Aqueous Solution by Cellulose-Carbonated Hydroxyapatite Nanocomposites. J. Hazard. Mater. 2011, 189, 755-763.

(35) Mobasherpour, I.; Salahi, E.; Pazouki, M. Comparative of the Removal of $\mathrm{Pb}^{2+}, \mathrm{Cd}^{2+}$ and $\mathrm{Ni}^{2+}$ by Nano Crystallite Hydroxyapatite from Aqueous Solutions: Adsorption Isotherm Study. Arabian J. Chem. 2012, 5, 439-446.

(36) Pandi, K.; Viswanathan, N. Enhanced Defluoridation and Facile Separation of Magnetic Nano-Hydroxyapatite/Alginate Composite. Int. J. Biol. Macromol. 2015, 80, 341-349.

(37) Lei, Y.; Guan, J.; Chen, W.; Ke, Q.; Zhang, C.; et al. Fabrication of Hydroxyapatite/Chitosan Porous Materials for $\mathrm{Pb}$ (II) Removal from Aqueous Solution. RSC $A d v$. 2015, 5, 25462-25470.

(38) Salah, T. A.; Mohammad, A. M.; Hassan, M. A.; El-Anadouli, B. E. Development of Nano-Hydroxyapatite/Chitosan Composite for Cadmium Ions Removal in Wastewater Treatment. J. Taiwan Inst. Chem. Eng. 2014, 45, 1571-1577.

(39) Li, L.; Iqbal, J.; Zhu, Y.; Zhang, P.; Chen, W.; Bhatnagar, A.; $\mathrm{Du}, \mathrm{Y}$. Chitosan/Ag-Hydroxyapatite Nanocomposite Beads as a Potential Adsorbent for the Efficient Removal of Toxic Aquatic Pollutants. Int. J. Biol. Macromol. 2018, 120, 1752-1759.
(40) Czerniczyniec, M.; Farías, S.; Magallanes, J.; Cicerone, D. Arsenic(V) Adsorption onto Biogenic Hydroxyapatite: Solution Composition Effects. Water, Air, Soil Pollut. 2007, 180, 75-82.

(41) Pandi, K.; Viswanathan, N. In Situ Precipitation of NanoHydroxyapatite in Gelatin Polymatrix towards Specific Fluoride Sorption. Int. J. Biol. Macromol. 2015, 74, 351-359.

(42) Manatunga, D. C.; de Silva, R. M.; de Silva, K. M. N.; Ratnaweera, R. Natural Polysaccharides Leading to Super Adsorbent Hydroxyapatite Nanoparticles for the Removal of Heavy Metals and Dyes from Aqueous Solutions. RSC Adv. 2016, 6, 105618-105630.

(43) Fernando, M. S.; De Silva, W. R. M.; De Silva, K. M. N. Modified Activated Carbon to Be Used in Clinical Applications. Int. J. Nanosci. 2014, 13, No. 1440002.

(44) Fernando, M. S.; De Silva, R. M.; De Silva, K. M. N. Synthesis, Characterization, and Application of Nano Hydroxyapatite and Nanocomposite of Hydroxyapatite with Granular Activated Carbon for the Removal of $\mathrm{Pb} 2+$ from Aqueous Solutions. Appl. Surf. Sci. 2015, 351, 95-103.

(45) Jeirani, Z.; Niu, C. H.; Soltan, J. Adsorption of Emerging Pollutants on Activated Carbon. Rev. Chem. Eng. 2017, 33, 491-522.

(46) Mondal, S.; Hoang, G.; Manivasagan, P.; Moorthy, M. S.; Kim, H. H.; Vy Phan, T. T.; Oh, J. Comparative Characterization of Biogenic and Chemical Synthesized Hydroxyapatite Biomaterials for Potential Biomedical Application. Mater. Chem. Phys. 2019, 228, 344-356.

(47) Sanchez, A. G.; Prokhorov, E.; Luna-Barcenas, G.; MoraGarcía, A. G.; Kovalenko, Y.; Rivera-Muñoz, E. M.; Grazia Raucci, M.; Buonocore, G. Chitosan-Hydroxyapatite Nanocomposites: Effect of Interfacial Layer on Mechanical and Dielectric Properties. Mater. Chem. Phys. 2018, 217, 151-159.

(48) Budnyak, T. M.; Pylypchuk, I. V.; Tertykh, V. A.; Yanovska, E. S.; Kolodynska, D. Synthesis and Adsorption Properties of ChitosanSilica Nanocomposite Prepared by Sol-Gel Method. Nanoscale Res. Lett. 2015, 10, No. 87.

(49) Mali, K. K.; Dhawale, S. C.; Dias, R. J.; Dhane, N. S.; Ghorpade, V. S. Citric Acid Crosslinked Carboxymethyl Cellulose-Based Composite Hydrogel Films for Drug Delivery. Indian J. Pharm. Sci. 2018, 80, 657-667.

(50) Alizadeh Asl, S.; Mousavi, M.; Labbafi, M. Synthesis and Characterization of Carboxymethyl Cellulose from Sugarcane Bagasse. J. Food Process. Technol. 2017, 08, No. 08.

(51) Kalinnikov, V. T.; Chalykh, A. E.; et al. HydroxyapatiteCarboxymethyl Cellulose Nanocomposite Biomaterial. Inorg. Mater. 2005, 41, 509-515.

(52) Pasqui, D.; Torricelli, P.; De Cagna, M.; Fini, M.; Barbucci, R. Carboxymethyl Cellulose-Hydroxyapatite Hybrid Hydrogel as a Composite Material for Bone Tissue Engineering Applications. J. Biomed. Mater. Res., Part A 2014, 102, 1568-1579.

(53) Calvo, T. A.; Santagapita, P. Physicochemical Characterization of Alginate Beads Containing Sugars and Biopolymers. J. Qual. Reliab. Eng. 2016, 2016, No. 9184039.

(54) Abo-El-Enein, S. Nitrate Removal from Groundwater Using Sodium Alginate Doped with Nano-Hydroxyapatite. Adv. Mater. 2017, 6, 102.

(55) Manatunga, D. C.; de Silva, R. M.; de Silva, K. M. N.; Malavige, G. N.; Wijeratne, D. T.; Williams, G. R.; Jayasinghe, C. D.; Udagama, P. V. Effective Delivery of Hydrophobic Drugs to Breast and Liver Cancer Cells Using a Hybrid Inorganic Nanocarrier: A Detailed Investigation Using Cytotoxicity Assays, Fluorescence Imaging and Flow Cytometry. Eur. J. Pharm. Biopharm. 2018, 128, 18-26.

(56) Hossan, J.; Gafur, M. A.; Kadir, M. R.; Mainul, M. Preparation and Characterization of Gelatin- Hydroxyapatite Composite for Bone Tissue Engineering. Int. J. Eng. Technol. 2014, 57, 113-122.

(57) Rouchon, V.; Pellizzi, E.; Janssens, K. FTIR Techniques Applied to the Detection of Gelatine in Paper Artifacts: From Macroscopic to Microscopic Approach FTIR Techniques Applied to the Detection of Gelatine in Paper Artifacts: From Macroscopic to Microscopic Approach. Appl. Phys. A 2010, 100, 663-669. 
(58) Isikli, C.; Hasirci, V.; Hasirci, N. Development of Porous Chitosan-Gelatin/Hydroxyapatite Composite Scaffolds for Hard Tissue-Engineering Applications. J. Tissue Eng. Regen. Med. 2012, 6, 135-143.

(59) Azami, M.; Samadikuchaksaraei, A. Synthesis and Characterization of a Laminated Hydroxyapatite/Gelatin Nanocomposite Scaffold for Bone Tissue Engineering. Int. J. Artif. Organs 2010, 33, $86-95$.

(60) Anwar, A.; Asghar, M. N.; Kanwal, Q.; Kazmi, M.; Sadiqa, A. Low Temperature Synthesis and Characterization of Carbonated Hydroxyapatite Nanocrystals. J. Mol. Struct. 2016, 1117, 283-286.

(61) Aydin, N. E. Effect of Temperature on Drug Release: Production of 5-FU-Encapsulated Hydroxyapatite-Gelatin Polymer Composites via Spray Drying and Analysis of In Vitro Kinetics. Int. J. Polym. Sci. 2020, 2020, No. 8017035.

(62) Lian, H.; Zhang, L.; Meng, Z. Biomimetic Hydroxyapatite/ Gelatin Composites for Bone Tissue Regeneration: Fabrication, Characterization, and Osteogenic Differentiation in Vitro. Mater. Des. 2018, 156, 381-388.

(63) Gopalakannan, V.; Viswanathan, N. Development of NanoHydroxyapatite Embedded Gelatin Biocomposite for Effective Chromium(VI) Removal. Ind. Eng. Chem. Res. 2015, 54, 1256112569.

(64) Yeh, J. J.; Lindau, I. Atomic subshell photoionization cross sections and asymmetry parameters: $1 \leqslant Z \leqslant 103$. At. Data Nucl. Data Tables 1985, 32, 1-155.

(65) Seah, M. P.; Dench, W. A. Quantitative Electron Spectroscopy of Surface. Surf. Interface Anal. 1979, 1, 2-11.

(66) Fernando, M. S.; De Silva, R. M.; De Silva, K. M. N. Synthesis, Characterization, and Application of Nano Hydroxyapatite and Nanocomposite of Hydroxyapatite with Granular Activated Carbon for the Removal of $\mathrm{Pb}^{2+}$ from Aqueous Solutions. Appl. Surf. Sci. 2015, 351, 95-103.

(67) Vieira, R. S.; Oliveira, M. L. M.; Guibal, E.; RodríguezCastellón, E.; Beppu, M. M. Copper, Mercury and Chromium Adsorption on Natural and Crosslinked Chitosan Films: An XPS Investigation of Mechanism. Colloids Surf., A 2011, 374, 108-114.

(68) Dambies, L.; Guimon, C.; Yiacoumi, S.; Guibal, E. Characterization of Metal Ion Interactions with Chitosan by X-Ray Photoelectron Spectroscopy. Colloids Surf., A 2001, 177, 203-214.

(69) Zhu, Y.; Zhu, Z.; Zhao, X.; Liang, Y.; Huang, Y. Characterization, Dissolution, and Solubility of Lead Hydroxypyromorphite $\left[\mathrm{Pb}_{5}\left(\mathrm{PO}_{4}\right) 3 \mathrm{OH}\right]$ at $25-45^{\circ} \mathrm{C}$. J. Chem. 2015, 2015, No. 269387.

(70) Barka, N.; Ouzaouit, K.; Abdennouri, M.; El Makhfouk, M.; Qourzal, S.; Assabbane, A.; Ait-Ichou, Y.; Nounah, A. Kinetics and Equilibrium of Cadmium Removal from Aqueous Solutions by Sorption onto Synthesized Hydroxyapatite. Desalin. Water Treat. 2012, 43, 8-16.

(71) Zhu, Y. N.; Zhang, X. H.; Xie, Q. L.; Wang, D. Q.; Cheng, G. W. Solubility and Stability of Calcium Arsenates at $25^{\circ} \mathrm{C}$. Water, Air, Soil Pollut. 2006, 169, 221-238.

(72) Ezzeddine, A.; Bedoui, A.; Hannachi, A.; Bensalah, N. Removal of Fluoride from Aluminum Fluoride Manufacturing Wastewater by Precipitation and Adsorption Processes. Desalin. Water Treat. 2015, 54, 2280-2292.

(73) Azami, M.; Jalilifiroozinezhad, S.; Mozafari, M.; Rabiee, M. Synthesis and Solubility of Calcium Fluoride/Hydroxy-Fluorapatite Nanocrystals for Dental Applications. Ceram. Int. 2011, 37, 20072014

(74) Wei, C.; Zhu, Y.; Yang, F.; Li, J.; Zhu, Z.; Zhu, H. Dissolution and Solubility of Hydroxylapatite and Fluorapatite at $25{ }^{\circ} \mathrm{C}$ at Different pH. Res. J. Chem. Environ. 2013, 17, 57-61.

(75) Levine, K. E.; Redmon, J. H.; Elledge, M. F.; Wanigasuriya, K. P.; Smith, K.; Munoz, B.; Waduge, V. A.; Periris-John, R. J.; Sathiakumar, N.; Harrington, J. M.; Womack, D. S.; Wickremasinghe, R. Quest to Identify Geochemical Risk Factors Associated with Chronic Kidney Disease of Unknown Etiology ( $\mathrm{CKDu}$ ) in an Endemic Region of Sri Lanka-a Multimedia Laboratory Analysis of
Biological, Food, and Environmental Samples. Environ. Monit. Assess. 2016, 188, No. 548.

(76) World Health Organization. Guidelines for Drinking-Water Quality. WHO Library Cataloguing-in-Publication Data Guidelines for Drinking-Water Quality; 4th ed.; WHO, 2017.

(77) Tomar, G.; Thareja, A.; Sarkar, S. Enhanced Fluoride Removal by Hydroxyapatite-Modified Activated Alumina. Int. J. Environ. Sci. Technol. 2015, 12, 2809-2818.

(78) He, J.; Chen, K.; Cai, X.; Li, Y.; Wang, C.; Zhang, K.; Jin, Z.; Meng, F.; Wang, X.; Kong, L.; Liu, J. A Biocompatible and NovellyDefined Al-HAP Adsorption Membrane for Highly Effective Removal of Fluoride from Drinking Water. J. Colloid Interface Sci. 2017, 490, 97-107.

(79) Fernando, M. S.; Wimalasiri, A. K. D. V. K.; Ratnayake, S. P.; Jayasinghe, J. M. A. R. B.; William, G. R.; Dissanayake, D. P.; de Silva, K. M. N.; de Silva, R. M. Improved Nanocomposite of Montmorillonite and Hydroxyapatite for Defluoridation of Water. RSC Adv. 2019, 9, 35588-35598.

(80) Pandi, K.; Viswanathan, N. Synthesis of Alginate Bioencapsulated Nano-Hydroxyapatite Composite for Selective Fluoride Sorption. Carbohydr. Polym. 2014, 112, 662-667.

(81) Yu, X.; Tong, S.; Ge, M.; Zuo, J. Removal of Fluoride from Drinking Water by Cellulose@hydroxyapatite Nanocomposites. Carbohydr. Polym. 2013, 92, 269-275.

(82) Ruan, Z. Y.; Tian, Y. X.; Ruan, J. F.; Cui, G. J.; Iqbal, K. W.; Iqbal, A.; Ye, H. R.; Yang, Z. Z.; Yan, S. Q. Synthesis of Hydroxyapatite/Multi-Walled Carbon Nanotubes for the Removal of Fluoride Ions from Solution. Appl. Surf. Sci. 2017, 412, 578-590.

(83) Nagaraj, A.; Munusamy, M. A.; Ahmed, M.; Suresh Kumar, S.; Rajan, M. Hydrothermal Synthesis of a Mineral-Substituted Hydroxyapatite Nanocomposite Material for Fluoride Removal from Drinking Water. New J. Chem. 2018, 42, 12711-12721.

(84) Sangeetha, K.; Vidhya, G.; Vasugi, G.; Girija, G. V. E. K. Lead and Cadmium Removal from Single and Binary Metal Ion Solution by Novel Hydroxyapatite/Alginate/Gelatin Nanocomposites. J. Environ. Chem. Eng. 2018, 6, 1118-1126.

(85) Pătescu, R. E.; Busuioc, L. T.; Nechifor, G.; Simonescu, C. M.; Deleanu, C. Applicability of Chitosan/Hydroxyapatite Composites for Adsorptive Removal of Lead, Copper, Zinc and Nickel from Synthetic Aqueous Solutions. UPB Sci. Bull., Ser. B 2017, 79, 119-134.

(86) Jayaweera, H. D. A. C.; Siriwardane, I.; de Silva, K. M. N.; de Silva, R. M. Synthesis of Multifunctional Activated Carbon Nanocomposite Comprising Biocompatible Flake Nano Hydroxyapatite and Natural Turmeric Extract for the Removal of Bacteria and Lead Ions from Aqueous Solution. Chem. Cent. J. 2018, 12, No. 18. 